\title{
Cerebellar Target Neurons Provide a Stop Signal for Afferent Neurite Extension in vitro
}

\author{
Douglas H. Baird, ${ }^{1,2}$ Mary E. Hatten, ${ }^{1}$ and Carol A. Mason ${ }^{1,2}$ \\ Departments of ${ }^{1}$ Pathology and ${ }^{2}$ Anatomy and Cell Biology, Center for Neurobiology and Behavior, Columbia University, \\ College of Physicians and Surgeons, New York, New York 10032
}

\begin{abstract}
The contributions of cell-cell interactions to the establishment of specific patterns of innervation within target brain regions are not known. To provide an experimental analysis of the regulation of afferent axonal growth, we have developed an in vitro assay system, based on the developing mouse cerebellum, in which afferent axons from a brainstem source of mossy fiber afferents, the basilar pontine nuclei, were cocultured with astroglia or granule neurons purified from the cerebellum. In the absence of cells from the cerebellum, pontine explants produced axons that fasciculated and extended rapidly on a culture surface treated with polylysine or laminin. When pontine neurites grew onto cerebellar astroglial cells, outgrowth was more abundant than on substrates alone, suggesting that glial cells provide a positive signal for axon extension. Time-lapse video microscopy indicated that the rate of neurite extension increased from less than $50 \mu \mathrm{m} / \mathrm{hr}$ to more than $100 \mu \mathrm{m} / \mathrm{hr}$ when axonal growth cones moved from the culture substratum onto an astroglial-cell surface. Acceleration of neurite extension was also observed as pontine neurites grew onto other pontine neurites.
\end{abstract}

By contrast, when pontine neurites grew on granule neurons, the appropriate targets of mossy fibers, the length of pontine neurites was greatly reduced. As growing axons terminated on granule neurons, the target cells appeared to provide a "stop-growing signal" for axon extension. The length of pontine neurites decreased with increasing granule neuron density. Two lines of evidence suggested that the stop signal was contact mediated. First, video microscopy showed that pontine growth cones stopped extending after contacting a granule neuron. Second, the length of afferent axons was not reduced when pontine neurites grew at a distance from granule neurons. Competition experiments where both astroglia and granule neurons were plated together suggested that the growth arrest signal provided by granule neurons could override the growth-promoting signal provided by astroglial cells. These results suggest that spe-

\footnotetext{
Received July 22, 1991; revised Sept. 24, 1991; accepted Sept. 27, 1991.

We appreciate the insightful comments of Drs. Carlos Baptista, Gord Fishell, Pierre Godement, Ron Liem, and Li-Chong Wang. Linda Friedman provided excellent technical and photographic assistance. Ray Manson helped with the photography, and Kenneth Wei, with word processing. This work was supported by NIH Grants NS16951 (C.A.M.), Program Project NS2145, and NRSA Postdoctoral Fellowship NS08761 (D.H.B.).

Correspondence should be addressed to Carol Ann Mason, Ph.D., Department of Pathology, Columbia University, College of Physicians and Surgeons, 630 West 168th Street, New York, NY 10032.

Copyright (C) 1992 Society for Neuroscience $0270-6474 / 92 / 120619-16 \$ 05.00 / 0$
}

cific cell-cell interactions regulate the growth of pontine afferent axons within their cerebellar target, with axoaxonal and axoglial interactions promoting axon extension and axontarget cell interactions interrupting axon extension.

A central problem in mammalian brain development is the identification of regulatory signals for afferent axon growth during the selection of specific neural targets. Studies on the development of axonal pathways in brain, including observations of Golgi-impregnated material (Ramon y Cajal, 1911) and individual dye-labeled axons in fixed (Bovolenta and Mason, 1987; Godement et al., 1990) and living brain (Harris et al., 1987; Godement and Mason, 1990; O'Rourke and Fraser, 1990; Sretavan, 1990; Stuermer, 1990), have provided evidence that axons grow rapidly as they leave their point of origin and extend in tracts toward their targets. Once afferent axons enter the target region, however, the pace of axon advance slows dramatically, and a prolonged period is required to establish patterns of specific innervation. Although cell-cell interactions have long been assumed to provide cues that guide developing axons, the relative contributions of fiber-fiber interactions among growing axons, of astroglial cells in the target region, and of specific target neurons to axon growth have not been defined.

The cerebellum provides a convenient model to analyze the regulation of afferent growth and axon-target cell interactions in mammalian CNS, because it has well-characterized and identifiable target cell populations and two prominent afferent systems, climbing and mossy fibers, which originate in brainstem and spinal sources. Mossy afferent systems form synaptic complexes called glomeruli with granule neuron dendrites (Palay and Chan-Palay, 1974; Landis et al., 1983). Neuroanatomical tracing methods have revealed the steps in afferent axon outgrowth, including the outgrowth of afferents through immature axon tracts, their invasion of the cerebellar anlage, and pattern of synaptogenesis with specific neuronal populations (Altman, 1982; Sotelo, 1982; Marin-Padilla, 1985; Mason, 1987; O'Donoghue et al., 1987; Gravel and Hawkes, 1990; Mason et al., 1990; C. A. Mason, S. Christakos, and R. Blazeski, unpublished observations). At each of these stages, cell-cell interactions are evident: axoaxonal and axoglial interactions within emerging axon tracts as neurites extend, and axon-target cell interactions in the cerebellar anlage.

A prominent component of the mossy fiber projection originates in the basilar pontine nuclei (Brodal and Walberg, 1977). In the mouse, pontine afferents emerge from the pontine nuclei at about embryonic days 18-19 (E18-E19) (Altman and Bayer, 1978; C. A. Mason and R. Blazeski, 1991). At about E19 to 
postnatal day $0(\mathrm{P} 0)$, the first pontine afferent axons reach the cerebellar anlage (Mason et al., 1990). Immunocytochemical labeling indicates the pathway taken by afferent growth cones is populated with immature astroglial cells (Bovolenta et al., 1984).

Within the developing cerebellar cortex, incoming mossy afferent axons grow toward the emerging Purkinje and granule cell layers and establish synaptic connections with target granule neurons in the internal granule cell layers. Over the first 2 postnatal weeks, mossy fibers interact with target granule neurons as well as temporary targets, the Purkinje cells. When the pontine axons first arrive, the internal granule cell layer is sparsely populated and many mossy fibers overshoot and extend toward the surface of the anlage. Immature granule neuron targets are found superficially, which migrate inward from the external granule cell layer. Mossy fibers have access to Purkinje cells that have begun to align into a monolayer interposed between migrating and settled granule neurons. Initially within this zone, some mossy fibers send off fine branches that contact both Purkinje and granule neurons, termed "combination fibers" (Mason and Gregory, 1984). Thereafter, specific mossy fiber-granule neuron circuits are established in the internal granule layer, and these persist through adulthood.

Although the pattern of axon projection, axon-target contacts, and synaptogenesis are well documented in the intact cerebellum, the regulation of these events remains unclear. To provide an experimental analysis of the extension of afferents and target cell selection, we have developed methods to culture afferent axonal components of the cerebellar system and to analyze their interactions with astroglia and target neurons in a defined system in vitro. We have begun with the granule neuron, since purified granule neurons can be obtained in high yield (Hatten, 1985), and with the pontine nuclei as one source of mossy fiber afferents. Our goal in these experiments was to provide a defined system to identify the cell-cell interactions that regulate afferent axon growth.

\section{Materials and Methods}

In the majority of experiments, we relied on interspecies cocultures, placing mouse explants on rat cells and visualizing the mouse explant neurites selectively with the M6 monoclonal antibody (Lund et al., 1985), specific to mouse neurons.

Explants of pontine nuclei. Intact brains were removed from newborn mice, and pontine nuclei were dissected by removing the overlying meninges and excising from the base of the brainstem the superficial swellings on the rostral portion of the pons, representing the basilar pontine nuclei. The intact tissue was washed once in Tyrode's calcium/ magnesium-free phosphate-buffered saline $\left(\mathrm{PBS}, 4^{\circ} \mathrm{C}\right)$ resuspended in serum-free medium, Eagle's basal medium with Earle's salts supplemented with glucose (final concentration, $32 \mathrm{~mm}$ ); penicillin/streptomycin (GIBCO; $20 \mathrm{U} / \mathrm{ml}$ each); $2 \mathrm{~mm}$ L-glutamine, $5 \mathrm{mg} /$ liter insulin, $5 \mathrm{mg} /$ liter transferrin, and $5 \mu \mathrm{g} /$ liter sodium selenite (Sigma, St. Louis, MO, medium supplement 1-1884); and 1\% bovine serum albumin (Sigma, fraction V). Excised pontine nuclei were cut into pieces between 100 and $300 \mu \mathrm{m}$ in diameter with a Beaver miniblade (catalog number 7545). Individual explants were washed in medium and transferred in $10 \mu \mathrm{l}$ aliquots with a pipette tip to a glass coverslip microculture dish (Hatten and Francois, 1981). Prior to the addition of the explants, the culture surface was pretreated overnight with polylysine (Sigma; 500 $\mu \mathrm{g} / \mathrm{ml}$ ) or polylysine followed by laminin (E-Y Laboratories; 20 or 50 $\mu \mathrm{g} / \mathrm{ml}, 2 \mathrm{hr}$ at $20^{\circ} \mathrm{C}$ ) and washed three times with distilled water or PBS. Approximately 10 explants were added to each coverslip dish. For coculture experiments, explants were added to cerebellar astroglia or granule neurons after $1 \mathrm{~d}$ in vitro.

To confirm that in mouse, as in other species, the basilar pontine nuclei project to cerebellum, newborn mice were anesthetized and fixed by perfusion with $4 \%$ paraformaldehyde. The middle cerebellar peduncles, in which pontine mossy fibers project to the cerebellum, were injected with the fluorescent tracer 1,1'-dioctodecyl-3,3,3',3'-tetramethylindocarbocyanine perchlorate (DiI) (Godement et al., 1987) by placing crystals of the dye suspended in Triton X-100 (Sigma) on the cut surface of the peduncles. After 1 month, the brains were sectioned on a vibratome at $100 \mu \mathrm{m}$ and viewed with fluorescence optics.

Purification of cerebellar astroglial cells and granule neurons. Cerebellar granule neurons and astroglia were purified on postnatal days 36 (P3-P6) as described previously for mouse cells (Hatten, 1985, 1987). For time-lapse video studies, mouse cells were used, and for cultures to be immunostained and quantitated, rat cells harvested from SpragueDawley rats (CAMM Inc.) were cocultured with pontine explants from mouse. In brief, a single-cell suspension was separated into high- and low-density (small and large cell) fractions on a 60-35-0\% Percoll step gradient. Purified granule neurons were obtained by two serial preplating steps of the small cell fraction (30 min each) on tissue culture plastic treated with poly-D-lysine, $100 \mu \mathrm{g} / \mathrm{ml}$. This method yields neuronal populations of at least $95-98 \%$ purity as judged by the small size and characteristic cytology of granule neurons (Hatten, 1985). Astroglia were obtained from the large cell fraction by preplating on polylysine-treated bacteriological plastic culture surface for $30 \mathrm{~min}$ and then washing off neurons, which adhere more slowly. This cell fraction is enriched for astroglia, but still contains some neurons.

Preplating was in Eagle's basal medium with Earle's salts (GIBCO) supplemented with horse serum (10\% GIBCO), glutamine ( 2 mm; GIB$\mathrm{CO}$ ), glucose (32 mM, final concentration), and penicillin-streptomycin $(20 \mathrm{U} / \mathrm{ml} \mathrm{each}$; GIBCO). Cells were replated at a final cell density of between 800 and 9600 cells $/ \mathrm{mm}^{2}$ in a final volume of $40 \mu \mathrm{l}$ in glass coverslip microcultures (Hatten and Francois, 1981). After 12-24 hr, the medium was changed to serum-free medium (see above) and a second coverslip was placed over the culture well in the glass coverslip microcultures. Cultures were maintained at $35.5^{\circ} \mathrm{C}$ with $100 \%$ humidity and $5 \% \mathrm{CO}_{2}$.

"Ceiling" coverslip cultures. To test for the effect of secreted factors on the growth of pontine explants, granule neurons or astroglia were plated at a final density of $3200-6400$ cells $/ \mathrm{mm}^{2}$ on polylysine-coated glass covcrslips (\#1, $22 \mathrm{~mm}$ diameter, Thomas Scientific), and the coverslips were inverted and placed across the top of microwells containing pontine explants, forming unsealed chambers (Bartlett and Banker, 1984). To control for the few cells that fell off the upper coverslip, landing among the explants, some cultures were incubated in an inverted fashion (cells beneath explants). Similar results were obtained in either situation.

Immunostaining. To identify murine pontine fibers, the cultures were immunostained with the mouse-specific M6 monoclonal antibody, generously provided by Dr. Carl Lagenauer (Lund et al., 1985). Neurites were identified by immunostaining with the NF2 monoclonal antibody against the 200,000 Da neurofilament protein (Liem et al., 1985), generously provided by our colleague Dr. R. K. H. Liem. Dendrites were distinguished from axons with antibodies to MAP2 (Huber and Matus, 1984; obtained from ICN). Astroglial cells and their processes were visualized by staining with antibodics against the glial filament protein (GFP), also provided by our colleague Dr. Liem (Liem, 1982).

For immunostaining, cultures were fixed in $4 \%$ paraformaldehyde $\left(0.1 \mathrm{~m}\right.$ phosphate buffer, $\mathrm{pH} 7.4,30 \mathrm{~min}, 20^{\circ} \mathrm{C}$ ). After washing three times in phosphate-buffered saline (PBS), the cultures were incubated in PBS containing $10 \%$ normal goat serum (NGS; $30 \mathrm{~min}, 20^{\circ} \mathrm{C}$ ) and $0.05 \%$ Triton X-100 (excluded for M6, a surface antigen), after which primary antibody diluted in PBS with 1\% NGS were added (M6 1:10, GFP 1:2000, NF2 1:50, MAP2 1:5000) overnight at $4^{\circ} \mathrm{C}$. After washing the cultures three times in PBS, peroxidase-, fluorescein-, or thodamineconjugated secondary antibodies were applied (M6, goat anti-rat conjugated with rhodamine $1: 100$ or peroxidase $1: 80 ;$ GFP, goat anti-rabbit conjugated with fluorescein $1: 100$ with $0.05 \%$ Triton $X-100 ; N F 2$ and MAP2, goat anti-mouse peroxidase conjugate $1: 100$ with $0.05 \%$ Triton $\mathrm{X}-100$ ) for $30 \mathrm{~min}$ at $20^{\circ} \mathrm{C}$. After washing three times in PBS, fluorcscently immunostained cultures were mounted in PBS : glycerol $(1: 9)$ with $p$-phenylenediamine $(0.1 \%)$ added as an antifading agent or in $\mathrm{Gel}$ Mount (Biomeda). For peroxidase labeling, cultures were incubated in $0.5 \mathrm{mg} / \mathrm{ml}$ diaminobenzidine (Dojin), $0.006 \% \mathrm{H}_{2} \mathrm{O}_{2}$ in PBS at $20^{\circ} \mathrm{C}$ (M6, $15 \mathrm{~min}$; GFP, MAP2, and NF2, 1-2 min). The peroxidase reaction was terminated by washing three times with PBS. After dehydration in ethanol, the coverslips were mounted on glass slides with Permount.

Quantitation of neurite outgrowth. After immunostaining with M6 to identify pontine neurites, the lengths of stained processes were measured using a Leitz Dialux 20 EB microscope fitted with a Zeiss $25 \times$ Neofluar 
phase objective, a Hipad Digitizer, a Zeos 286 computer, and the Bioquant System IV (R\&M Biometrics Inc., Nashville, TN). A set of concentric rings of apparent radii of 150,200 , and $300 \mu \mathrm{m}$ was visualized through a drawing tube and centered on the image of the explant. The number of neurites crossing the rings at each distance was then recorded. Neurites from 10-20 explants were quantitated for each culture condition of every experiment. Results from individual experiments are presented, but for each condition at least three experiments were quantitated.

Differential interference contrast video microscopy. For video microscopy, after $36-48 \mathrm{hr}$ in vitro, the culture medium was changed to a medium identical to the serum-free medium described above, but buffered with HEPES $(15 \mathrm{~mm})$. In some experiments Earle's salts were replaced with Charles' salts (Edmondson and Hatten, 1987). To identify the fibers of pontine origin, explants were separated from cerebellar cells at the time of plating using a removable plastic (aclar) wall, and their neurites could thus be easily traced from the growth cone back to their explant of origin. The behavior of growth cones as they approached the edge of the field of granule cells was observed with video-enhanced differential interference contrast (VEDIC) microscopy (Allen et al., 1981; Inouye, 1986; Edmondson and Hatten, 1987). The video analyses were made just as the first wave of neurites from the explant grew out toward the half of the dish containing granule cells, since it is extremely difficult to follow explant neurites once they have grown among the granule cells, which themselves have neurites.

The image was acquired with a Hamamatsu Chalnicon video camera mounted on a Zeiss IM35 or Axiovert microscope fitted for Nomarski optics, and recorded on a Panasonic Optical Memory Disc Recorder. On the IM35, a $63 \times$ planapochromat objective was used, while on the Axiovert, Zeiss Plan-Neofluar 20 and $100 \times / 1.3$ NA oil immersion objectives were used. A Uniblitz shutter was interposed between the 100 W mercury lamp and microscope tube. Images were recorded every 5$30 \mathrm{sec}$ at high magnification to every $5 \mathrm{~min}$ at lower magnification, with shutter-opening times of 0.5-1 sec. An Image-1 computer system (Universal Imaging Inc.) was used to increase image contrast, average images, and subtract background images, as well as to trigger the shutter and optical memory disk recorder.

Measurement of growth cone rates. Images stored on the optical memory disk recorder were displayed sequentially and quantitated using the Image-1 image processing computer system. The position of each growth cone was recorded every $5 \mathrm{~min}$ at high magnification $(160 \times)$ or every $30 \mathrm{~min}$ at low magnification $(32 \times)$. At high power, the points of maximum extension up, down, left, and right of each growth cone were tracked. The positions of these points were averaged, and the mean was used as the growth cone position for each image measured. The distance the growth cones traveled between images at $5 \mathrm{~min}$ intervals was calculated, and these rates were plotted as a function of time. At low power, the position of maximum advance in the direction of growth of each growth cone was recorded every $30 \mathrm{~min}$, and the distance covered in every $30 \mathrm{~min}$ interval was plotted against time as a mean rate every $\mathbf{3 0}$ $\min$.

\section{Results}

\section{Characterization of outgrowth from pontine explants}

To examine pontine afferent fiber outgrowth in vilro, we prepared small explants $(100-300 \mu \mathrm{m})$ of the pontine nuclei and plated them in microculture dishes (Hatten and Francois, 1981) on coverslips pretreated with either polylysine or laminin. Under the conditions described, over $95 \%$ of the explants extended neurites on laminin, and over $80 \%$ on polylysine, within $48 \mathrm{hr}$ of plating (Figs. $1 A-F, 2 B, 3 A, B$ ), suggesting that the first step in afferent axon projection, initiation of neurite extension, occurred in the absence of cerebellar glia or neurons. On both of these substrates, growth cones develop large, widened flanks and numerous filopodia (Fig. $3 B$ ).

The amount of outgrowth from the explants differed on polylysine- and laminin-treated substrates, with more extensive outgrowth evident on laminin. By light microscopic visualization of neurofilament-positive fibers and by electron microscopy (not shown), afferent neurites were highly fasciculated on a polyly- sine-coated substrate (Fig. $3 B$ ). In addition, small branchlets and filopodia extended from neurites, which is likely the result of multiple growth cones within a single fascicle (Fig. $3 A, B$ ). On a laminin-treated surface, neurite fasciculation was less prominent and the total length of individual neurites was longer than that seen on polylysine, as evidenced by the increased frequency of neurites longer than $300 \mu \mathrm{m}$ (Figs. $1 C, D ; 2 A, B$ ).

To determine whether the explant outgrowth was neuronal, we immunostained cultures with the NF2 antibody, raised against the 200,000 Da neurofilament protein. The majority of explant neurites were NF2 positive (Fig. $1 C, D$ ). To visualize glial elements in the explanted pontine nuclei and to determine the contribution of glial fibers to the population of fibers that extended from the explants, we immunostained cultures with antibodies against GFP. Although stained astroglial cells were abundant within the explants (Fig. $1 A, B$ ), we rarely observed GFP-positive fibers extending from the explant.

To determine whether explant neurites were axonal or dendritic, we immunostained explants with antibodies to the microtubule-associated protein MAP2, a marker for dendritic processes (Huber and Matus, 1984). Dense immunostaining was seen within the explant, but few darkly labeled neurites extended from the explant (Fig. $1 E, F$ ). This suggests that outgrowth from the pontine explants is principally axonal.

To confirm that in mouse, as in other species (Brodal and Walberg, 1977), the basilar pontine nuclei project to the cerebellum at the time explants were taken, we backfilled pontine neurons by injecting Dil into fixed neonatal cerebellum (not shown). Cell bodies were labeled throughout the entire width and breadth of the nuclei, confirming that the majority of neurons project to the cerebellum. Moreover, previous studies from our laboratory indicate that when rhodamine isothiocyanate is injected into the basilar pontine nuclei at birth, anterogradely labeled fibers terminated within the cerebellar anlage, primarily in the internal granule cell layer. Such injections at later periods and in the adult labeled mossy fibers with characteristic morphology and trajectory (Mason et al., 1990).

\section{Pontine neurite extension in coculture with cerebellar astroglia}

Astroglial cells were purified from P3-P6 cerebellum by methods previously described (Hatten, 1985, 1987). To distinguish afferent pontine explants and their neurites from cells of the monolayer on which they were plated, we cocultured mouse pontine nuclei with dissociated rat cells and immunostained cultures with a mouse-specific monoclonal antibody M6 (Lund et al., 1985) to identify pontine fibers. The M6 antibody clearly revealed fine pontine neurites, with patches of continuous labeling alternating with punctate staining (Fig. 2), and permitted us to trace individual neurites from the edge of the explant to their endings among glial cells or granule neurons (Fig. $2 A-D$ ). The staining of filopodia by M6 highlighted the palmate appearance of mossy fiber growth cones (Fig. 2C). Dissociated rat cerebellar cells did not label with M6 (Fig. $2 E, F$ ).

When explants were placed on a monolayer of cells enriched for astroglia, robust pontine neurite outgrowth was seen. The length of pontine neurites on enriched glial monolayers was greater than that observed on a polylysine-coated surface (Fig. $4 A$ ), with the longest neurites exceeding $500 \mu \mathrm{m}$ in length. Moreover, the degree of fasciculation decreased on a glial substrate (compare Fig. $3 A, E$ ). Glia plated at a range of densities, from 800 to 3200 cells $/ \mathrm{mm}^{2}$, supported abundant pontine neurite outgrowth. 

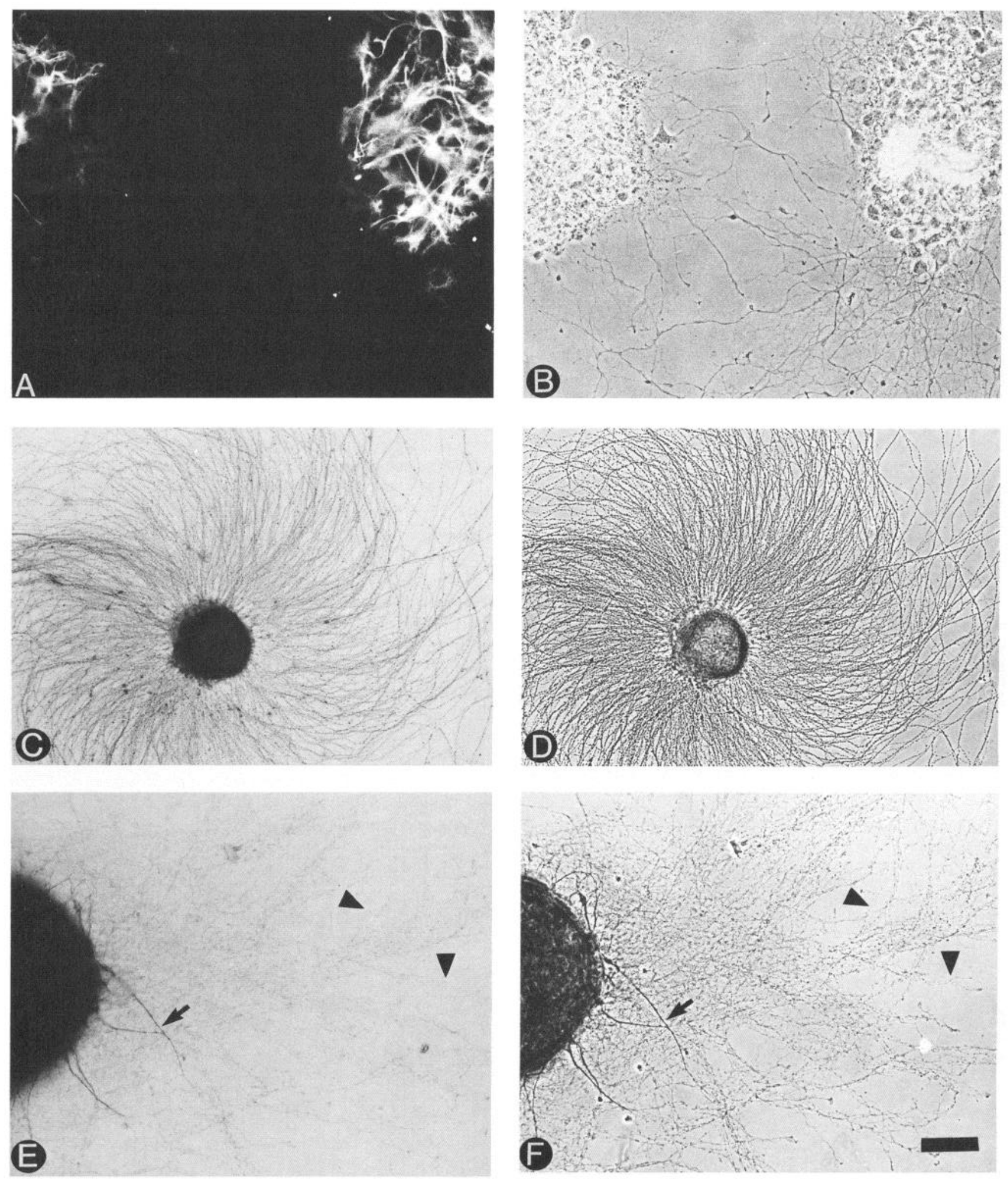

Figure 1. Outgrowth from pontine nuclei explants is axonal. A, Pontine explants cultured for $2 \mathrm{~d}$ on polylysine, fixed, and immunolabeled with antiserum to GFP; fluorescence optics. Astrocytes in the body of the explant are brightly labeled. $B$, Same explants, phase optics. Fibers that extend from the explant are GFP negative. $C$, Explant cultured on laminin for $2 \mathrm{~d}$, fixed, and immunostained with a monoclonal antibody, NF2, which recognizes the high molecular weight neurofilament protein; bright field. All, or almost all, fibers visible in $D$ are labeled, indicating that outgrowth is neuritic. $D$, Same explant, phase optics. E, Explants cultured for $2 \mathrm{~d}$ on polylysine, fixed, and labeled with a monoclonal antibody to the microtubule-associated protein MAP2 found in dendrites. The arrow indicates where a pair of thick, relatively short processes that labeled with MAP2 extend out from the explant. These MAP2-positive fibers represent a small fraction of the processes that extend from the explant. Arrowheads point to examples of long, finer-diameter fibers extending from the explant that have little or no MAP2 labeling. These fibers make up the bulk of explant outgrowth and are probably axonal. F, Same explant, phase optics. Fibers with little or no MAP2 labeling are visible (e.g., arrowheads). Scale bar: $40 \mu \mathrm{m}$ for $A$ and $B, 120 \mu \mathrm{m}$ for $C$ and $D ; 50 \mu \mathrm{m}$ for $E$ and $F$. 
To examine whether astroglial cells promoted axon growth by cell surface interactions or by providing soluble factors, we compared the number of pontine neurites from explants cultured on monolayers of glial cells with those where glial cells were cultured above the explants on a separate, suspended glial "ceiling" coverslip. The length of pontine ncurites was grcater on glial monolayers than on polylysine with a glial ceiling, the latter matching growth on polylysine without a glial ceiling (Fig. $4 B$ ). This suggests that the major component of glial support of mossy fiber extension in vitro was provided by contact with the glial cell.

By video microscopy, the primary influence of the glial substrate was a striking increase in the rate of pontine neurite extension. When pontine neurite growth cones shifted from the polylysine surface onto astroglial cells, their rate of advance accelerated rapidly from a speed of less than $50 \mu \mathrm{m} / \mathrm{hr}$ on a polylysine substrate to rates higher than $100 \mu \mathrm{m} / \mathrm{hr}$ on a glial monolayer (Figs. 5, 6). The growth cones of pontine neurite that extended rapidly on astroglia maintained an expanded base, lamellopodia, and filopodia, as they did on polylysine or laminin.

\section{Pontine neurite extension in coculture with cerebellar granule neurons}

To examine pontine neurite extension in the presence of their targets, cerebellar granule neurons, we plated pontine nuclei explants with purified granule neurons taken from early postnatal animals (P3-P6). The most pronounced effect of coculturing pontine explants with cerebellar granule neurons was a decrease in the length of the pontine neurites (Fig. 3). Pontine neurites in coculture with granule neurons were found to be axonal; pontine neurites were labeled with antibodies to the 200,000 Da neurofilament protein, but did not label with antibodies to the dendrite-specific protein MAP2 or to GFP (data not shown). Quantitation of the number of pontine axons 150$300 \mu \mathrm{m}$ in length emanating from pontine explants cocultured with granule neurons showed a reduced number of long neurites compared to explants grown on polylysine or laminin substrates (Figs. 3, 4A, 7). Whereas numerous fibers measuring more than $500 \mu \mathrm{m}$ were seen in coculture with glial cells, in coculture with granule neurons a fringe of short neurites less than $150 \mu \mathrm{m}$ bordered the explant, with neurites terminating at clusters of granule neurons. The large elaborate growth cones seen on poly- lysine or laminin condensed into tapered endings when pontine neurites were cocultured with granule neurons. In contrast to highly fasciculated growth on polylysine, pontine neurites extended singly near or in smaller bundles on granule neurons. Similar results were obtained using laminin as a substrate (Fig. 74). The major difference was that pontinc cxplants grew longer neurites on laminin than on polylysine (Fig. 7), but the foldreduction in pontine neurite lengths when cocultured with granule neurons on either of these substrates was similar.

To determine the number of granule neurons required to reduce pontine neurite lengths, explants were cocultured on monolayers of granule neurons of increasing density. A reduction in neurite lengths between 150 and $200 \mu \mathrm{m}$ was first seen with $3200 \mathrm{cells} / \mathrm{mm}^{2}$. Further reductions were observed at granule neuron concentrations of 6400 and 9600 cells $/ \mathrm{mm}^{2}$ (Fig. 7). At 6400 cells $/ \mathrm{mm}^{2}$, a four- to fivefold reduction in neurite lengths was observed compared to control explants grown on both polylysine and laminin substrata.

To investigate whether the interruption of afferent neurite extension seen in coculture with granule neurons required contact of pontine growth cones with cerebellar target granule neurons, wc carricd out four types of analyses. First, in normal cocultures of pontine explants and granule neurons, we examined neurites that grew in areas of low granule neuron density. Neurites that did not encounter granule neurons extended for up to $500 \mu \mathrm{m}$, far in excess of neurites encountering granule neurons in the same culture well (less than $150 \mu \mathrm{m}$ ). Second, we cultured pontine explants on polylysine with a coverslip of confluent granule neurons suspended as a "ceiling" above the explants. Explants with a granule neuron ceiling showed neurite lengths comparable to those grown with a polylysine ceiling, that is, showed no reduction in length (Fig. $4 B$ ). In contrast, when explants were grown directly on granule neurons, the number of long neurites (150-300 $\mu \mathrm{m}$ ) was reduced four- to fivefold compared to control explants (Fig. 4A). Third, explants from mouse pontine nuclei were plated at a distance from mouse granule neurons, by dividing the culture in half with a removable plastic wall and plating granulc neurons on one side of the wall, explants on the other. After cells and explants adhered to the polylysine or laminin substrate, the wall was removed. Over a field of granule neurons, explants extended short neurites, whereas on polylysine or laminin surfaces, explants extended long neurites. Explants that fell on the boundary of the two fields ex-

\footnotetext{
Figure 2. The monoclonal M6 labels outgrowth from mouse pontine nuclei explants but not rat cerebellar cells. $A$, Pontine explant from mouse cultured on laminin for $2 \mathrm{~d}$, fixed, and labeled with M6. Abundant M6-positive fibers can be traced from the explant. $B$, Same explant, phase optics. All fibers visible also label with M6 $(A)$. $C$, Coculture of murine pontine explant with dissociated rat cerebellar cells cultured on polylysine for $2 \mathrm{~d}$, fixed, and labeled with M6. The white arrowhead indicates the distal tip of a neurite, or small bundle of neurites that labeled with M6. Labeled neurites can be traced to their tips even when growing over and among numerous rat cerebellar cells, visible in phase $(D)$. $D$, Same field, phase optics. The arrow indicates a group of rat cerebellar cells that have little or no contact with M6-labeled pontine neurites, and are unlabeled (C). The black arrowhead indicates an example of rat cerebellar cells closely opposed to a pontine neurite. The pontine neurite labels with M6, but the processes of the rat cells extending away from the labeled neurite are unlabeled $(C) . E$, Dissociated rat cerebellar cells do not label with M6. $F$, Same field, phase view. Scale bar, $25 \mu \mathrm{m}$ for $A-F$.

Figure 3. Outgrowth of pontine neurites is extensive on polylysine and astroglia but not on granule neurons. Pontine nuclei explants from mouse, cultured for $3 \mathrm{~d}$, fixed, and labeled with the mouse-specific antibody M6 using the immunoperoxidase method. $A$, On polylysine, abundant outgrowth emanates from the explant body $(P) . B$, On polylysine, high magnification. Neurites often appear to terminate in growth cones (arrows) with many filopodia. Neurites often grow in small bundles on polylysine; sometimes individual neurites leave and reenter the bundles (e.g., arrowhead). $C$, On granule neurons, many short neurites extend from cxplant, tcrminating among granule neurons. Rare neurites extend for longer distances. $D$, On granule neurons, high magnification. The arrow indicates a labeled pontine neurite that forms the outermost portion of the fringe of short fibers. Many unlabeled fibers originating from the granule neuron fraction are also visible in phase optics (e.g., arrowhead). Granule neuron somata are numerous (e.g., $G$ ). $E$, On astroglial fraction. Profuse neurite outgrowth extends from explant. $F$, On astroglia, high magnification. Single fibers or smaller neurite bundles are more prevalent than on polylysine $(A$ and $B$ ). Scale bar: $50 \mu \mathrm{m}$ for $A, C$, and $E ; 20 \mu \mathrm{m}$ for $B, D$, and $F$. $A$ and $C$ appear in Mason and Godement (1991); reprinted with permission.
} 

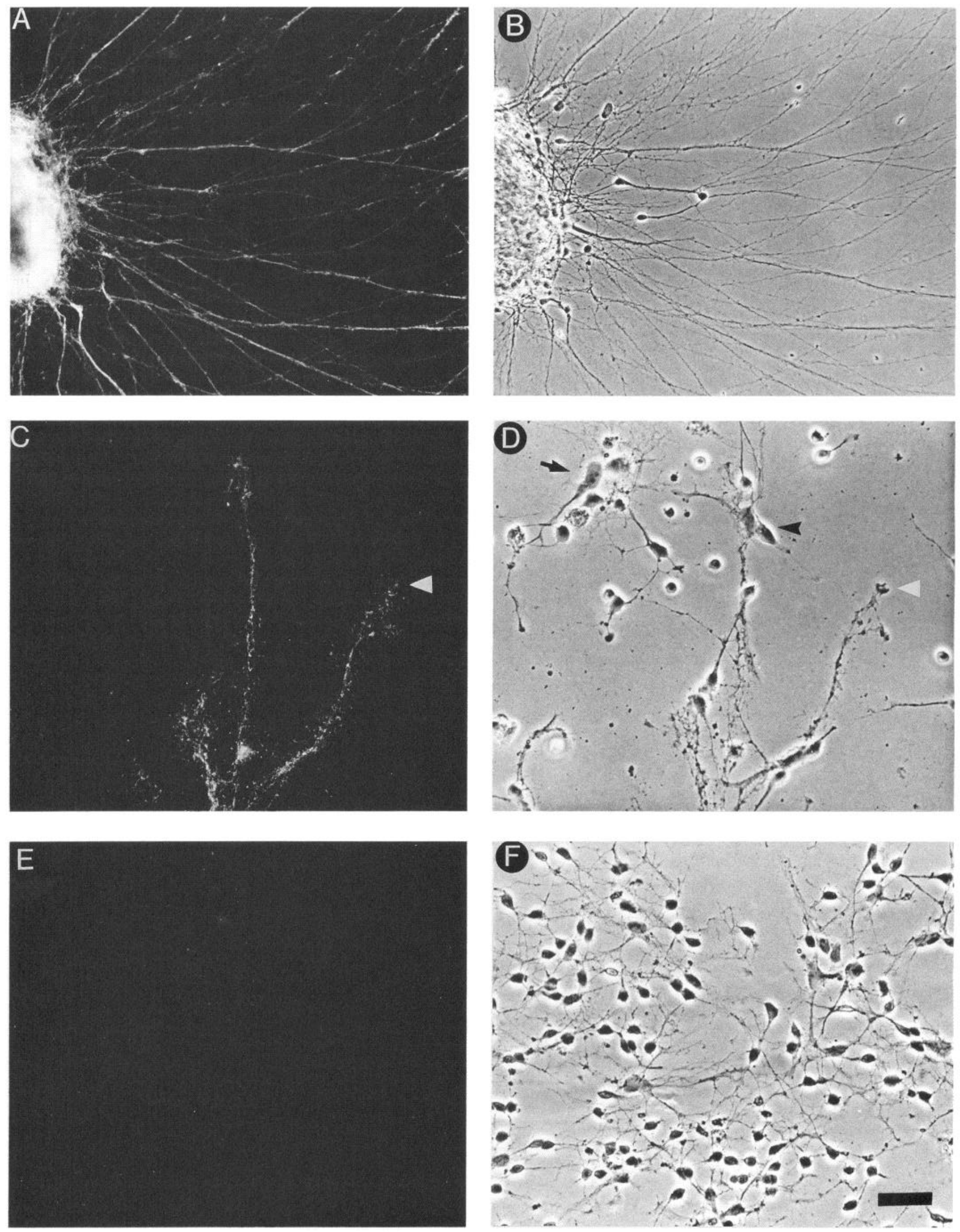

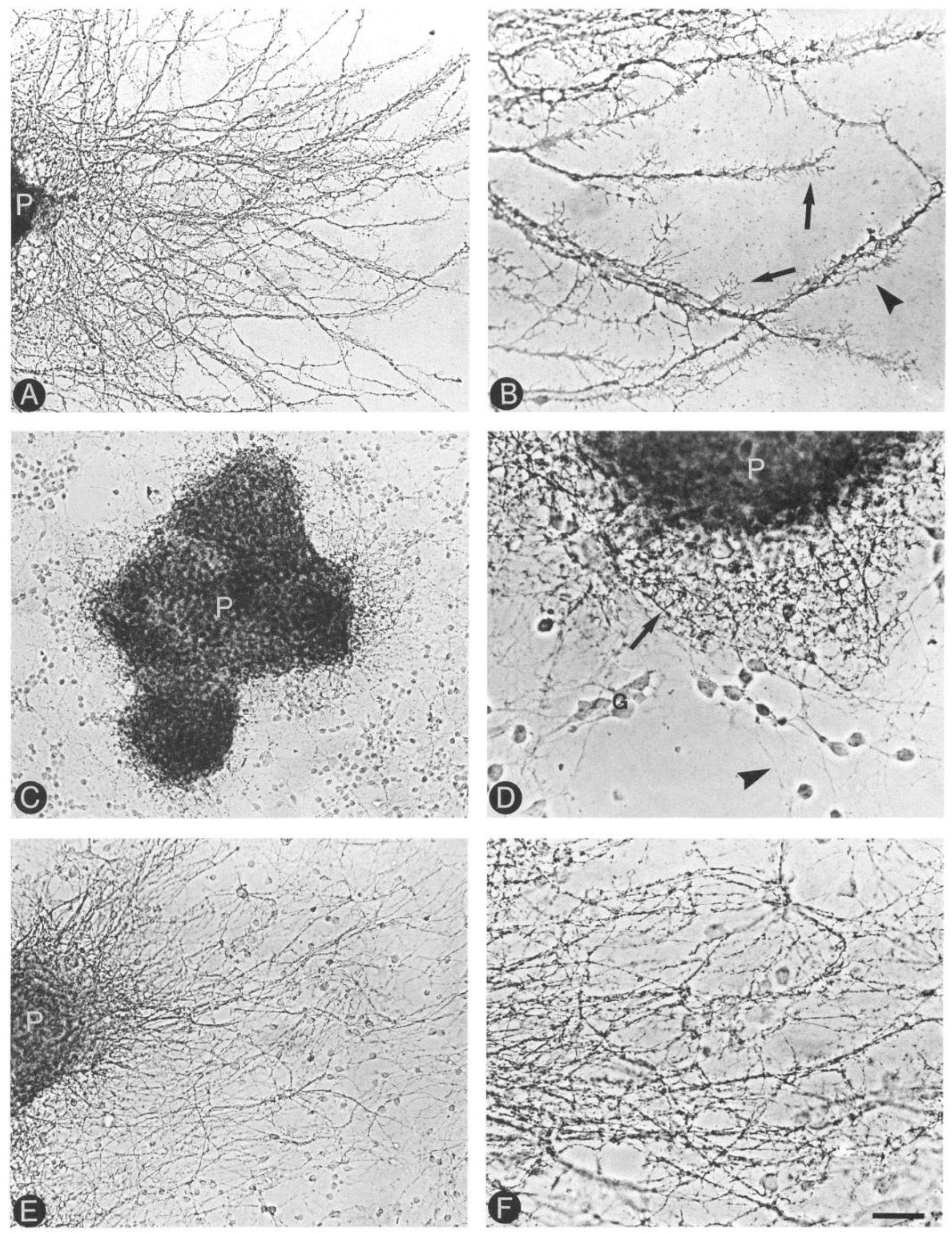


\section{A EXPLANTS ON CELLS OR POLY-LYSINE}

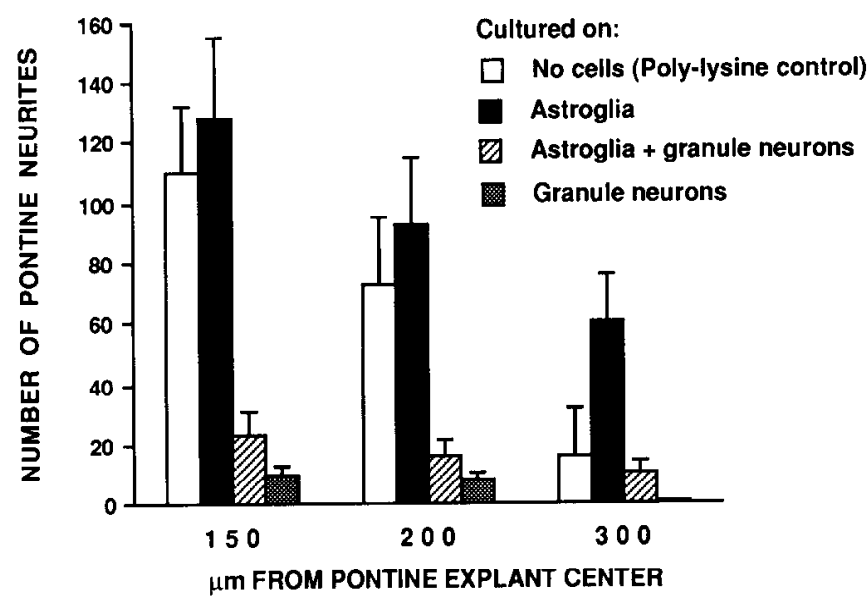

B EXPLANTS ON POLY-LYSINE WITH "CEILINGS"

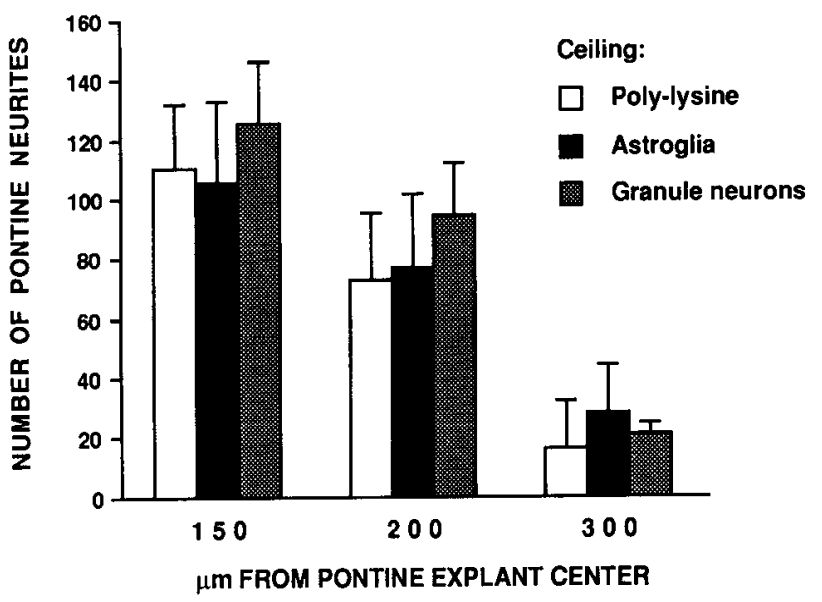

Figure 4. Quantitation of neurite outgrowth from pontine nuclei explants cultured alone or cocultured with astroglia or granule neurons. $A$, After $2 \mathrm{~d}$ in vitro, explants grown on astroglia plated at 3200 cells/ $\mathrm{mm}^{2}$ (solid bar; 9 explants) show increased neurite outgrowth compared to polylysine (open bar; 11 explants), cspecially in the number of neurites extending $300 \mu \mathrm{m}$ or more from the explant center. Explants grown on granule neurons plated at 6400 granule neurons $/ \mathrm{mm}^{2}$ (shaded bar; 9 explants) have 5-10-fold fewer neurites longer than $150 \mu \mathrm{m}$ compared to growth on polylysine or astroglia. If explants are plated on the same density of granule neurons with astroglia added back, a similar reduction in the number of neurites compared to growth on granule neurons alone is observed (hatched bar; 9 explants). $B$, Number of pontine neurites on polylysine with cellular or polylysine ceiling coverslips. After $2 \mathrm{~d}$ in vitro, there is little or no difference in the lengths of neurites grown under a ceiling of granule neurons plated at 6400 cells $/ \mathrm{mm}^{2}$ (shaded bar; 15 explants), glia at 3200 cells $/ \mathrm{mm}^{2}$ (solid bar; 15 explants), or polylysine (open bar; 11 explants). Error bars are SE of the mean.

tended long neurites onto polylysine or laminin, whereas neurites were much shorter on the granule neurons and tended to grow singly (Fig. 8).

Fourth, VEDIC microscopy showed that the cessation of pontine neurite extension did not occur when neurites simply grew near an area containing granule neurons, but rather followed cell-cell contacts between pontine growth cones and granule neurons. Whereas pontine growth cones elongated rapidly, up to $50 \mu \mathrm{m} / \mathrm{hr}$, on the polylysine substrate, growth cones stopped elongating upon contacting granule neurons (Figs. 9-11). In over 20 cases, pontine neurites stopped elongating after contacting granule neurons, within the period during which they were observed (between 1 and $16 \mathrm{hr}$ ) (Figs. 10, 11). By video microscopy, the cessation of axon growth involved close apposition between growth cones and granule neurons (Fig. 9). As the growth cone approached the granule neuron, initial contact was via filopodia on both the pontine growth cone and the granule neuron. Although pontine filopodial movements often continued for several hours, neurite extension ceased (Figs. 9-11).

To test whether homotypic fiber-fiber interactions among pontine neurites would serve as a stop signal for pontine neurites, we observed homotypic contacts between different pontine fibers. Contact between two pontine growth cones resulted in fasciculation and rapid extension of the pontine neurites. Extension increased to a maximal rate of $60-70 \mu \mathrm{m} / \mathrm{hr}$ when pontine growth cones advanced on pontine neurites (not shown). Thus, both pontine axons and cerebellar glia supported accelerated pontine growth cone advance, while contact with granule neurons arrested pontine neurite advance.

\section{Granule neuron arrest of pontine axon growth in the presence of glia}

To determine the relative ability of astroglia and granule neurons to regulate pontine neurite extension, we carried out two experiments. In the first case, we added cells of the astroglial fraction (at a density known to support abundant axon outgrowth, 3200 cells $/ \mathrm{mm}^{2}$ ) to cultures of granule neurons at a density that provides a strong stop signal $\left(6400\right.$ cells $\left./ \mathrm{mm}^{2}\right)$. Pontine neurite outgrowth was reduced to a level comparable to that seen on granule neurons alone (Fig. $4 A$ ), suggesting that granule neuron arrest of pontine neurite extension predominates over glial support of neurite extension.

In a second set of experiments, we cocultured pontine explants with cerebellar granule neurons on one coverslip and suspended a monolayer of glial cells on a "ceiling" coverslip suspended above them (not shown). The presence of an astroglia-enriched ceiling had little or no effect on the ability of granule neurons to arrest the extension of pontine neurites.

\section{Discussion}

In the developing brain, as axons enter target regions, they appear to slow their rate of advance and select specific target cells (Harris et al., 1987; O'Rourke and Fraser, 1990; Stuermer, 1990). The present findings utilizing an in vitro model system with purified populations of axons, astroglia, and target neurons suggest that in the cerebellum, specific contact-mediated interactions regulate the extent and rate of axon advance. Two types of cell-cell interactions increase the rate of growth of afferent axons. First, homotypic interactions among growing axons increase the rate of axon growth by a mechanism that involves axon fasciculation. Second, cerebellar astroglial cells also provide a positive signal for axon extension, with axoglial contacts acting to increase the rate of axonal extension. By contrast, interactions between pontine axons and their neural targets, the granule neurons, interrupt afferent axon extension by a mechanism that requires close apposition of the cells.

\section{Homotypic interactions among pontine axons promote axon growth}

The present in vitro analyses demonstrate that, in the absence of cerebellar target cells, pontine axons extend rapidly on a 

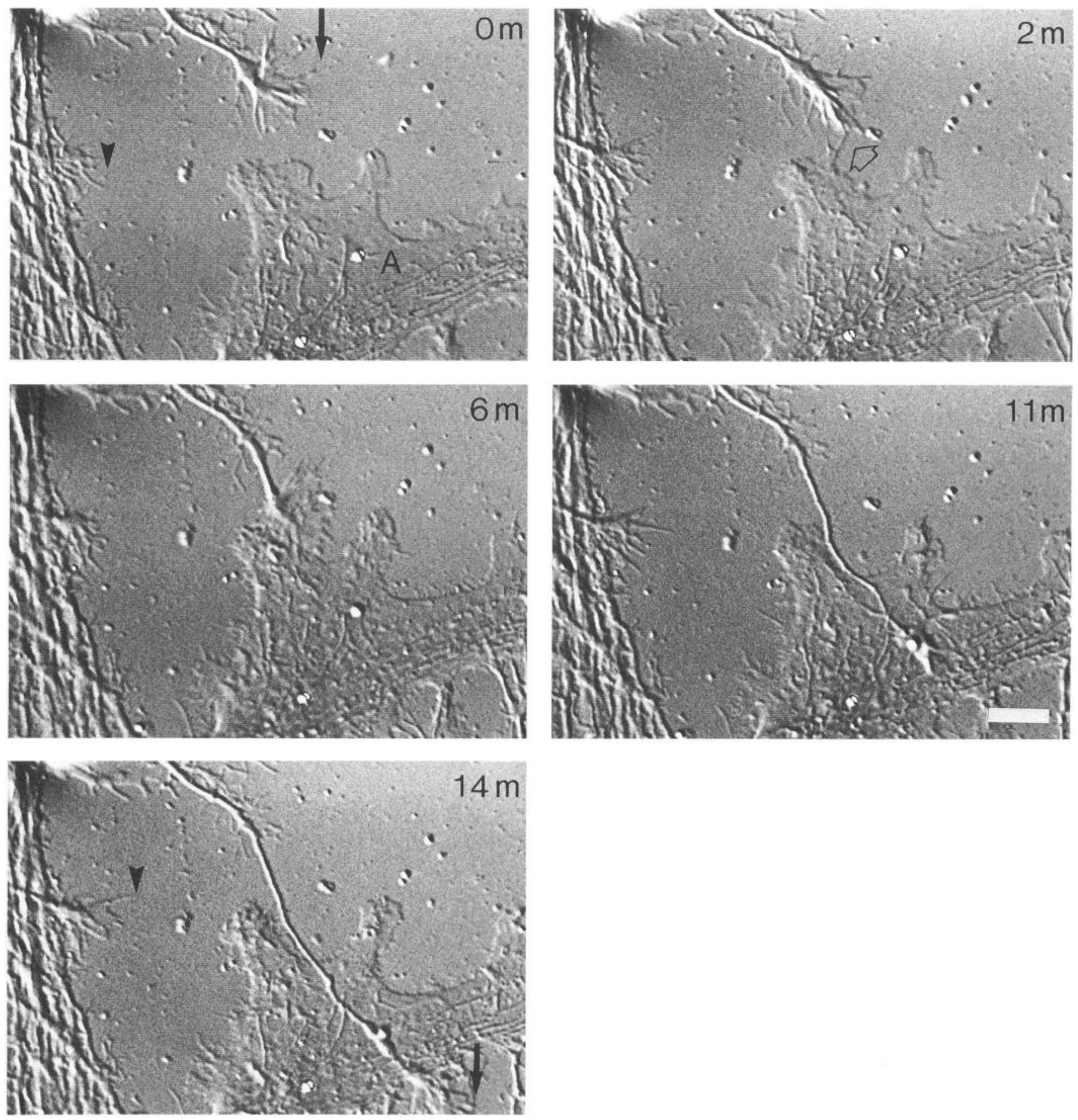

Figure 5. Pontine growth cone extension on astroglia. VEDIC time-lapse photomicrographs of a pontine neurite growing onto an astroglia cell over $14 \mathrm{~min} .0 \mathrm{~m}$, A pontine growth cone (arrow) approaches a cell of the astroglial fraction $(A)$. Another growth cone also advances on polylysine, but farther from the astroglial cell (arrowhead). $2 \mathrm{~m}$. Initiation of close apposition between growth cone and astroglial cell involves protrusions from both cells (open arrows). Growth cone rapidly extends onto the astroglial cell $(6 \mathrm{~m})$ and advances over the cell $(11 \mathrm{~m})$. By $14 \mathrm{~m}$, the growth cone has crossed the cell and portions of it now overlie the polylysine substrate on the opposite side of the cell (arrow). By comparison, the growth cone advancing on polylysine has extended a relatively short distance (arrowhead). Scale bar, $10 \mu \mathrm{m}$.

culture substratum treated with polylysine or laminin. Video microscopic analyses of axon extension from pontine explants in vitro demonstrated that axons interact in the absence of target cells, extending rapidly after fasciculation with other pontine axons. Moreover, the present experiments provide evidence that the rate of extension of afferent axons increased when the axons fasciculated in vitro. This result is consistent with a large number of studies in both vertebrate (Dodd and Jessell, 1988; Jessell, 1988; Rutishauser and Jessell, 1988) and invertebrate systems (Harrelson and Goodman, 1988) showing that axon fasciculation is associated with neurite extension. Antibody perturbation analyses (Thanos et al., 1984; Neugebauer et al., 1988; Burns 
Figure 6. Velocity of pontine growth cones as they approach and contact astroglia. Graphs in $A$ and $B$ represent interactions similar to that illustrated in Figure 5. Arrows indicate the time the pontine neurite growth cone first contacted an astroglial cell, while arrowheads show the time growth cone reached the opposite edge of cell. After contact, growth cone velocity increases 10 - or 30 -fold in contacts $A$ or $B$, respectively.
A

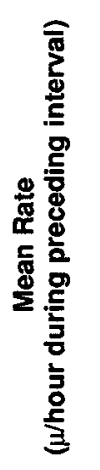

B

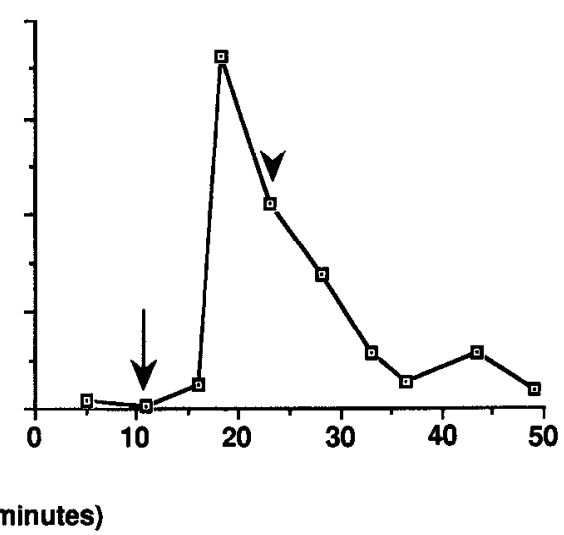

et al., 1991), genetic analyses (Elkins et al., 1990), and laser inactivation studies (Jay and Keshishian, 1990) provide evidence that several classes of neural adhesion molecules of the IgG superfamily, including the N-CAM and the L1 families of axonal glycoproteins, function in axoaxonal interactions of certain classes of neural cells.

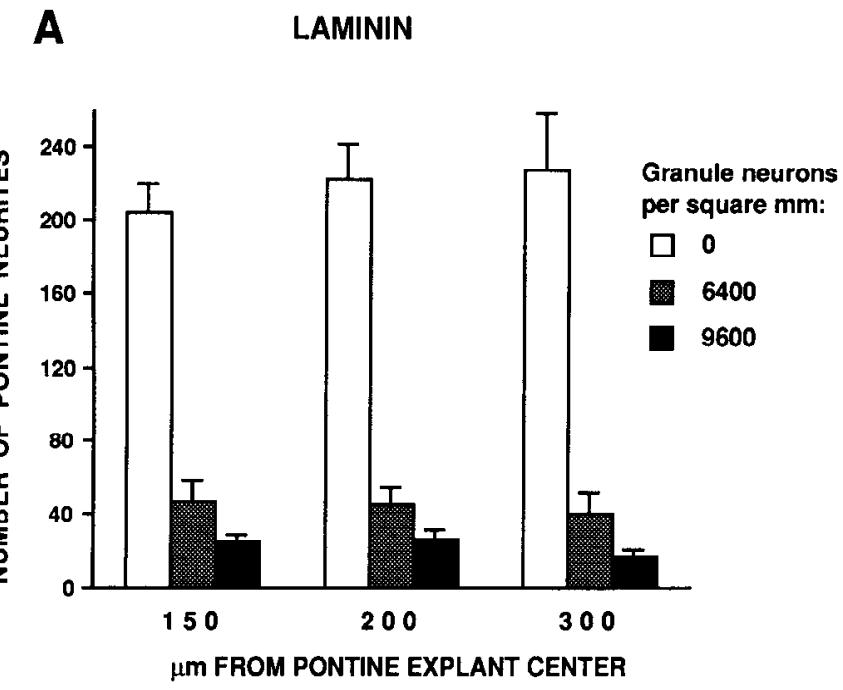

B POLY-LYSINE

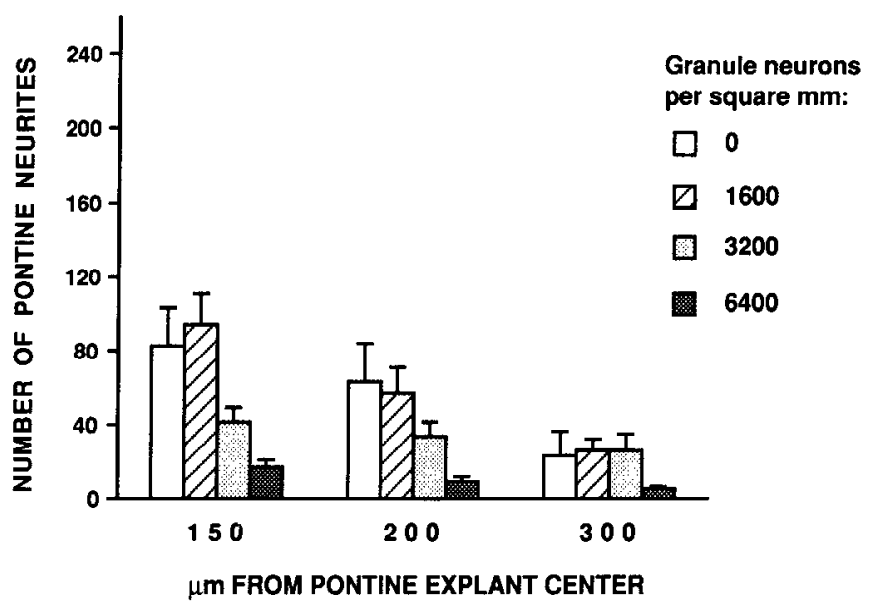

The behavior of pontine afferent axons that we observed in vitro reproduced several key features of mossy fiber growth in vivo. DiI labcling of growing axons has revealed that pontine axons grow in a separate tract on the perimeter of the brainstem, occupied primarily by pontine axons. In this tract, homotypic axoaxonal interactions (Hatten et al., 1991; Yaginuma et al., 1991) predominate during the period of axon growth from the basilar pons to the cerebellar anlage. Moreover, the rate of growth through the tract is extremely rapid, as mossy fibers grow to their entry to the cerebellar anlage, the medial cerebellar peduncles, covering a distance of over $1500 \mu \mathrm{m}$ within $1 \mathrm{~d}$ (Mason and Blazeski, unpublished observations).

\section{Astroglia promote pontine axon extension}

The findings that cerebellar astroglial cells foster extensive neurite outgrowth from pontine nuclei and that axoglial interactions increase the rate of pontine axon extension are consistent with a large body of evidence that astroglia support axon extension in vitro (Noblc ct al., 1984; Fallon, 1985; Armson ct al., 1987; Tomaselli et al., 1988; Wang et al., 1990) and in vivo (Smith et al., 1986). The mechanism of glial support of pontine neurite extension we observed in the present in vitro studies appeared to require close apposition of the cells, since the rate of growth increased when the axons contacted astroglia. A novel aspect of the present experiments was the use of astroglial cells purified from the appropriate target region at the developmental time when pontine axons arrive in the cerebellar cortex.

Our finding that astroglial cells in the target region support afferent axon growth is also consistent with the disposition of astroglial cells within the cerebellum at the time when pontine axons enter the cerebellar anlage. In the first postnatal week, GFP-positive astroglia first appear in the white matter and deeper layers of the anlage, the zone where granule neurons are

Figure 7. Pontine neurite outgrowth on increasing densities of granule neurons. $A$, Plating granule neurons on laminin at densities of 6400 or 9600 cells $/ \mathrm{mm}^{2}$ results in a 5 - or 10 -fold decrease in the number of pontine neurites extending more than $150 \mu \mathrm{m}$ from the explant center, respectively. Number of explants quantitated: 11 for 0 cells $/ \mathrm{mm}^{2}, 8$ for 6400 cells $/ \mathrm{mm}^{2}, 13$ for 9600 cells $/ \mathrm{mm}^{2}$. B, On polylysine, plating 1600 cells $/ \mathrm{mm}^{2}$ has little or no effect on neurite lengths or numbers, but at 3200 cells $/ \mathrm{mm}^{2}$, a $50 \%$ or $30 \%$ decrease is seen at distances of 150 or $200 \mu \mathrm{m}$, respectively. At a density of $6400 \mathrm{cells} / \mathrm{mm}^{2}$ reductions in neurite numbers of three- to fourfold are achieved. Number of explants quantitated: 16 for 0 cells $/ \mathrm{mm}^{2}, 22$ for 1600 cells $/ \mathrm{mm}^{2}, 13$ for 3200 cell $/ \mathrm{mm}^{2}, 24$ for 6400 cells $/ \mathrm{mm}^{2}$. Error bars are SE of the mean. 


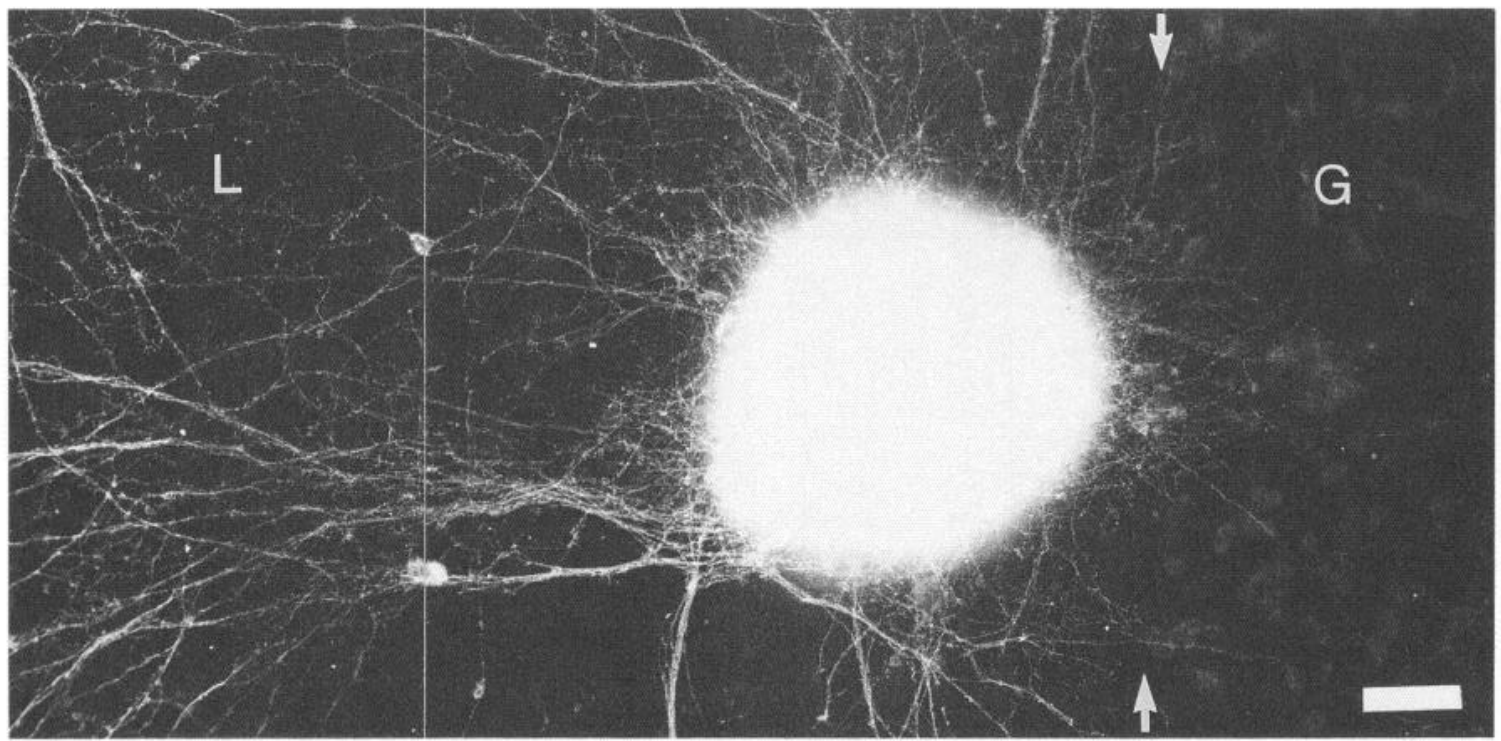

Figure 8. Neurite outgrowth from a pontine nuclei explant positioned on the boundary between a field of granule neurons on laminin and laminin alone. Many neurites extend for hundreds of microns over the laminin substrate $(L, l e f t)$. Neurites growing into the field of granule neurons $(G$, right) are shorter and terminate among the granule neurons. Arrows indicate the approximate location of the boundary between granule neurons on laminin and laminin alone. Scale bar, $50 \mu \mathrm{m}$.

establishing the internal granule cell layer after their migration along the Bergmann glia (Rakic, 1971; Hatten et al., 1984) and through the Purkinje cell layer (Bovolenta et al., 1984). The present experiments suggest that astroglial cells act to support axon extension as the fibers exit the tract and begin to ramify within the internal granule cell layer.

Two general mechanisms could provide a molecular basis of cerebellar astroglial support of pontine neurite outgrowth. First, antibody perturbation studies demonstrate that cell adhesion molecules, including neural cell adhesion molecules of the IgG superfamily (cadherins and integrins), promote axon extension on glial substrates in vitro (Tomaselli et al., 1988; Rutishauser, 1989; Reichardt et al., 1991). Astroglial cells have also been shown to provide extracellular matrix components that support axon growth, including laminin and heparan sulfate. Second, astroglial cells provide growth factors that promote axon extension. Among these, basic fibroblast growth factor (bFGF) is likely to function in a membrane-bound state, as experiments by Yayon et al. (1991) suggest that cell surface heparin-like molecules are required for the binding of bFGF to high-affinity receptors. Our observation that glial cells support rapid afferent axon growth via close apposition of the axon with the glial cell surface is consistent with either of these models of glial support of axon growth, or of a combinatorial model involving utilization of both cell surface adhesion systems and cell surfacebound growth factors.

\section{Pontine axon growth is arrested by granule neurons}

The findings that granule neurons reduce the length of pontine neurites in vitro suggest that target neurons provide a stop signal for afferent axon extension. Video microscopy experiments confirmed that the mechanism of inhibition of pontine neurite extension involved the formation of cell-cell contacts with granule neurons, initially involving filopodia. Filopodial contacts have also been shown to precede formation of neuron-glia contacts (Mason et al., 1988) and axon-guidepost cell interactions in the insect limb (O’Connor et al., 1990). Moreover, video microscopy experiments demonstrated that afferent axons stopped extending for a relatively long time period, up to $16 \mathrm{hr}$. During that period, afferent axons maintained contact with the target cell, rather than withdrawing or overshooting their targets. The time periods of growth inhibition observed in vitro were long relative to the rate of extension of the axon prior to the formation of contact with the target cell (up to $50 \mu \mathrm{m} / \mathrm{hr}$ ) and relative to the time required in vivo for axon growth from their cell body of origin in the pontine nuclei to the target ( $24 \mathrm{hr})$. Thus, it is likely that the interruption of axon extension we observed provided the first step in the formation of a stable contact with the target cell.

Observations of pontine axons in coculture with granule neurons for longer time periods (2-3 d) indicate that some axons relate to more than one cluster of granule neurons. This suggests that pontine neurites can reinitiate extension at a later time, an interpretation supported by the pattern of mossy fiber innervation of granule neurons in vivo. During the first 2 postnatal weeks, mossy axons bear a series of swellings, the ones most proximal and closest to the white matter appearing most mature in form and those most distal having the form of a growth cone with filopodia (Mason and Gregory, 1984). This pattern of innervation could result from a "stop-start" mechanism, with periods of intermittent growth lasting hours to days. The leading growth cone establishes synaptic contacts with a group of granule neurons, forming a synaptic glomerulus. Additional growth proceeds via a single filopodium of the leading growth cone, which gives rise to a new growth cone. Subsequent contacts result in an en passant arrangement of synaptic boutons (Ramon y Cajal, 1911; Landis et al., 1983; Mason and Gregory, 1984).

The mechanism of granule neuron arrest of pontine axon extension appeared to require close apposition of the cells. By video microscopy, the cessation of pontine neurite extension did not occur when pontine neurites simply grew near an area containing granule neurons; rather, it followed cell-cell contacts between pontine growth cones and granule neurons. Moreover, 

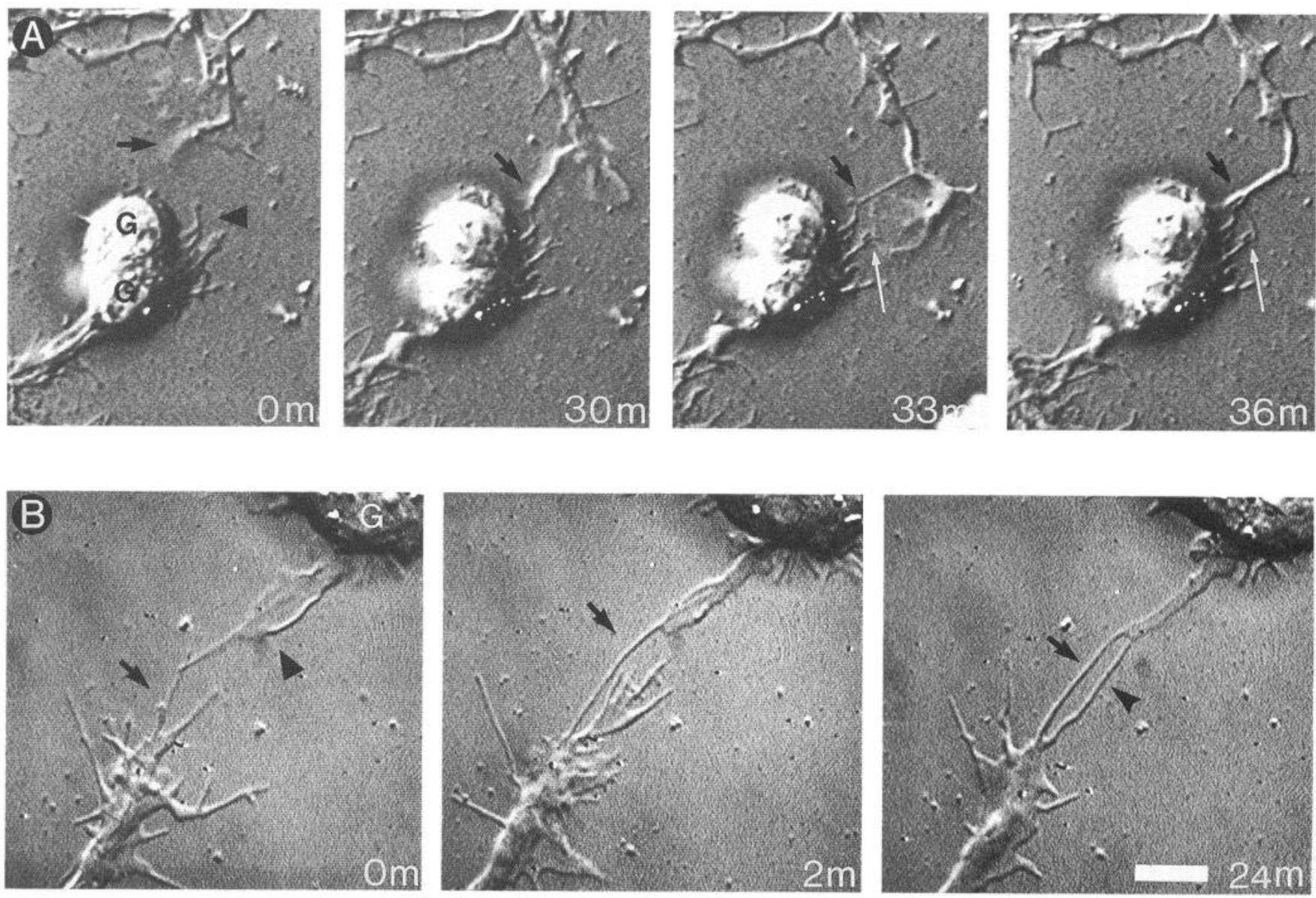

Figure 9. Pontine growth cones stop extending at granule neurons: VEDIC time-lapse photomicrographs of pontine growth cones contacting granule neurons. $A$, At $0 m$, growth cone (arrow) extends toward granule neuron somata $(G)$. Granule neuron extends processes (arrowhead) as well as the growth cone. At $30 \mathrm{~m}$, protrusions on growth cone and granule neuron appear to make contact (arrow). This contact is maintained at $33 \mathrm{~m}$ (black arrow), and an additional contact forms involving a growth cone veil (white arrow). At $36 \mathrm{~m}$, the veil has collapsed, leaving a contact between filopodia (white arrow), while the filopodium involved in the initial contact has enlarged (black arrow). B, Granule neuron filopodium (arrowhead) and growth cone filopodium (arrow) immediately after contact $(0 \mathrm{~m})$. At $2 \mathrm{~m}$, protrusions appear to fuse and can no longer be distinguished as individual filopodia (arrow). This contact is maintained (arrow, $24 \mathrm{~m}$ ) and has come to involve a second pair of filopodia (arrowhead). Scale bar, $6 \mu \mathrm{m}$.

the form of pontine growth cones before and after contact with targets closely resembled the forms seen in vivo (Mason, 1987; Mason et al., 1990). Well-extended, spread growth cones with filopodia are common as axons exit tracts and enter the cerebellar target region, as well as on laminin, polylysine, and astroglial substrates, all of which support rapid growth. Collapsed, budlike tips are seen when growth cones are in contact with target cells in the intact cerebellum (Mason and Blazeski, unpublished observations) and cerebral cortex (Norris and Kalil, 1990; Catalano and Killackey, 1991). The present experiments suggest that after a pause in axon extension, the next step of synaptogenesis with a target cell involves the condensation of the growth cone to a tapered ending.

The present study did not address the question as to whether the stop signal observed with granule neurons is specific to particular classes of neurons or to particular developmental stages of any given neuronal class. Preliminary results indicate that pontine neurite growth is not arrested by cell fractions enriched for Purkinje neurons, an inappropriate target for pontine afferents (D. H. Baird and C. A. Baptista, unpublished observations). In other experiments examining whether granule neurons would interrupt the growth of inappropriate afferent axons, the length of climbing fibers (afferents to Purkinje cells) was not reduced in coculture with granule neurons (Baird et al., 1990). In addition, retinal afferents extend long neurites on granule neurons (D. H. Baird and L.-C. Wang, unpublished observations). The experiments on the cerebellar system are consistent with earlier observations of dopaminergic afferent axon interactions with neurons from their striatal target region in vitro (Denis-Donini et al., 1983) showing that striatal neurons, but not cerebellar neurons, reduce the lengths of dopaminergic afferent neurites. Thus, for two systems analyzed to date, specific cell-cell interactions between afferent axons and target neurons appear to provide a regulatory signal for axon elongation.

Competition studies between the growth-promoting signals provided by astroglia and the inhibitory signals provided by granule neurons suggested that axon-target interactions dominate axoglial interactions in the regulation of axonal growth. These studies demonstrated that the reduced length of pontine neurites seen when the axons grew on a field of granule neurons was not altered by the addition of astroglial cells, even when the number of astroglia added was eight times an amount found to increase pontine neurite outgrowth in the absence of granule neurons. The predominance of the inhibitory signal from gran- 
A

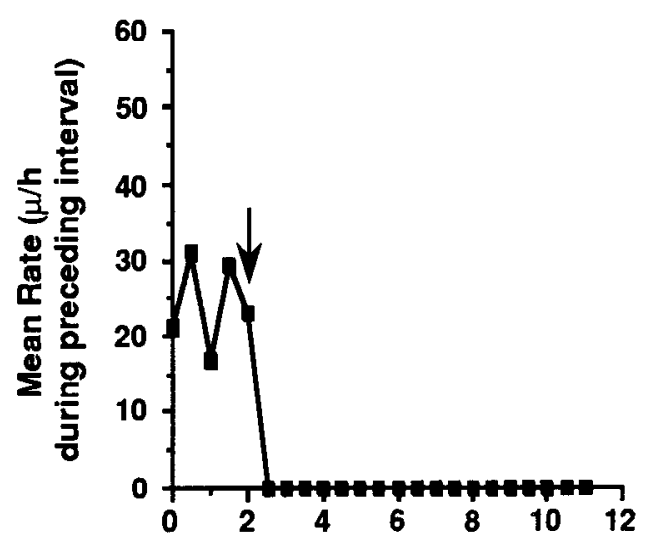

B

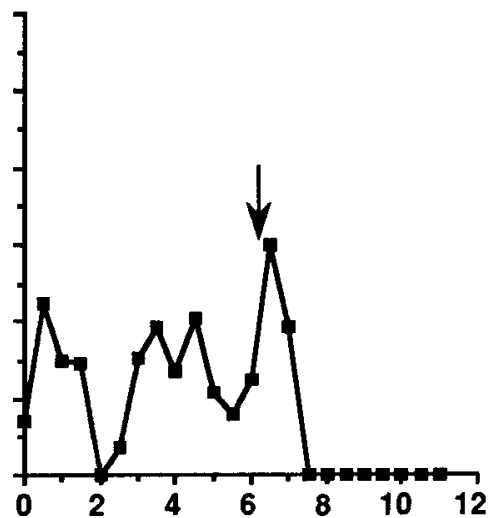

C

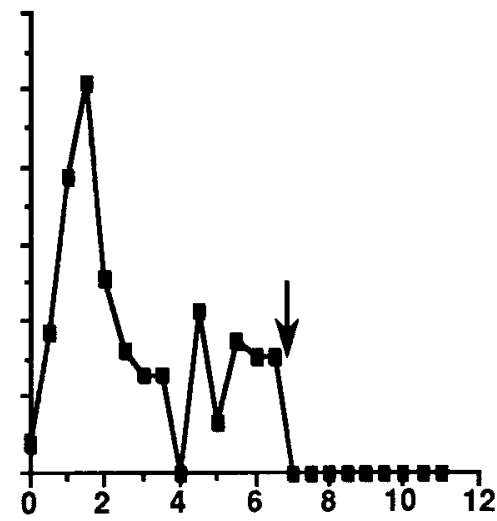

Time (hours)

Figure 10. Velocity of pontine growth cones encountering granule neurons. $A-C$ represent three separate growth cone-granule neuron interactions. Arrows indicate time of initial contact. In $A$ and $C$, a decrease in the rate of growth cone advance was abrupt, while in $B$, the growth cone was active for just over $30 \mathrm{~min}$ before finally ceasing to advance. Contacts established by growth cones were maintained throughout the observation period, over $8 \mathrm{hr}$ in $A$, although growth cones became immotile neurites during the early stages of contact. Before contact, growth cone velocity on polylysine ranged between 0 and a maximum of $50 \mu \mathrm{m} / \mathrm{hr}$. Spontaneous pauses in growth cone advance on polylysine were infrequent and lasted less than $1 \mathrm{hr}$, after which growth cone advance resumed, in contrast to the extended interruptions in growth following contacts with granule neurons.

ule neurons is consistent with the situation in vivo, where mossy fibers exit the developing white matter and ramify in fields of newly arrived granule neuron targets. In spite of the presence of astroglial cells, the mossy fibcrs transit from growth in tracts to cessation of growth in the internal granule cell layer. It is likely, then, that astroglial cells serve to promote the growth required until axons reach the first target cells and, subsequently, as they take up extension again to move onto the next group of targets. Moreover, the reduced fasciculation of pontine neurites observed in vitro in static and real-time preparations suggests an additional role for astroglia in splintering the bundles of fasciculated pontine afferents in the tract, into single afferents growing in the fields of target cells.

\section{Mechanisms of arrest of axon growth by target cells}

Our observation that afferent axons stopped growing upon contact with granule neurons shares some features with a number of examples of "contact inhibition" of cell motility. The most general case of cell-cell contact inhibition of cell motility, that provided by studies on fibroblast locomotion by Abercrombie and Heaysman (1953), indicates that the velocity of movement of individual fibroblasts is decreased upon contact with another fibroblast and that the extent of reduction in motility is proportional to the number of cell-cell contacts formed. In the nervous system, several examples of cessation of growth cone elongation after contact with other neurons or non-neuronal cells have been reported (Kapfhammer and Raper, 1987; Walter et al., 1987; Patterson, 1988; Ivins and Pittman, 1989; Bandtlow et al., 1990; Keynes and Cook, 1990; Moorman and Hume, 1990; Tosney and Oakley, 1990). These include inhibition of axon extension after contact with heterotypic axons, inhibition after contact with mammalian oligodendrocytes, and inhibition after contact with astroglial cells in certain states of differentiation (Wang et al., 1990; Baorto and Shelanski, 1990). As seen in the present study of pontine axons interacting with cerebellar granule neurons, and in cases of inhibition of growth cone advance by heterologous axons or glia, the initial contact of the growing axon with an inhibitory cell was by filopodia (Kapfhammer and Rapcr, 1987; Bandtlow ct al., 1990). The functional consequences of inhibitory interactions of growth cones, however, differed widely in these systems. In the case of cerebellar axon-target cell interactions, inhibition provides the initial step in the establishment of synaptic contacts and the patterning of afferent arbors on target neurons. In the case of retinal axons, contacts with a different class of axon (Kapfhammer and Raper, 1987) or cells from an inappropriate region of the target (Walter et al., 1987) led to collapse, retraction, or redirection of the growth cone.

The molecular mechanisms that interrupt axon extension have not been fully characterized. Recent studies on axoaxonal inhibition and on axoglial inhibition provide evidence that novel membrane components cause the collapse of growth cones (Kapfhammer and Raper, 1987; Bandtlow et al., 1990; Cox et al., 1990; Davies et al., 1990; Raper and Kapfhammer, 1990). At present, it is assumed that the latter factors represent a new class of molecules. An alternative possibility is that contact between the afferent growth cone and target cell leads to rapid downregulation, or removal via release or proteolysis of cell surface adhesion systems that promote neurite extension, including neural cell adhesion molecules of the IgG superfamily, cadherins and integrins (Jessell, 1988).

Numerous in vivo studies support a role for neural activity in the regulation of axon extension (Landmesser et al., 1990; for review, see Shatz, 1991). In vitro studies on the role of neurotransmitters and calcium levels in axon growth in vitro also suggest that alterations in the level of neural activity can be correlated with the arrest of axon growth of certain classes of neurites (for review, see Lipton and Kater, 1989). Preliminary evidence indicates that there is an activity-dependent component in the arrest of pontine neurite extension by target granule 

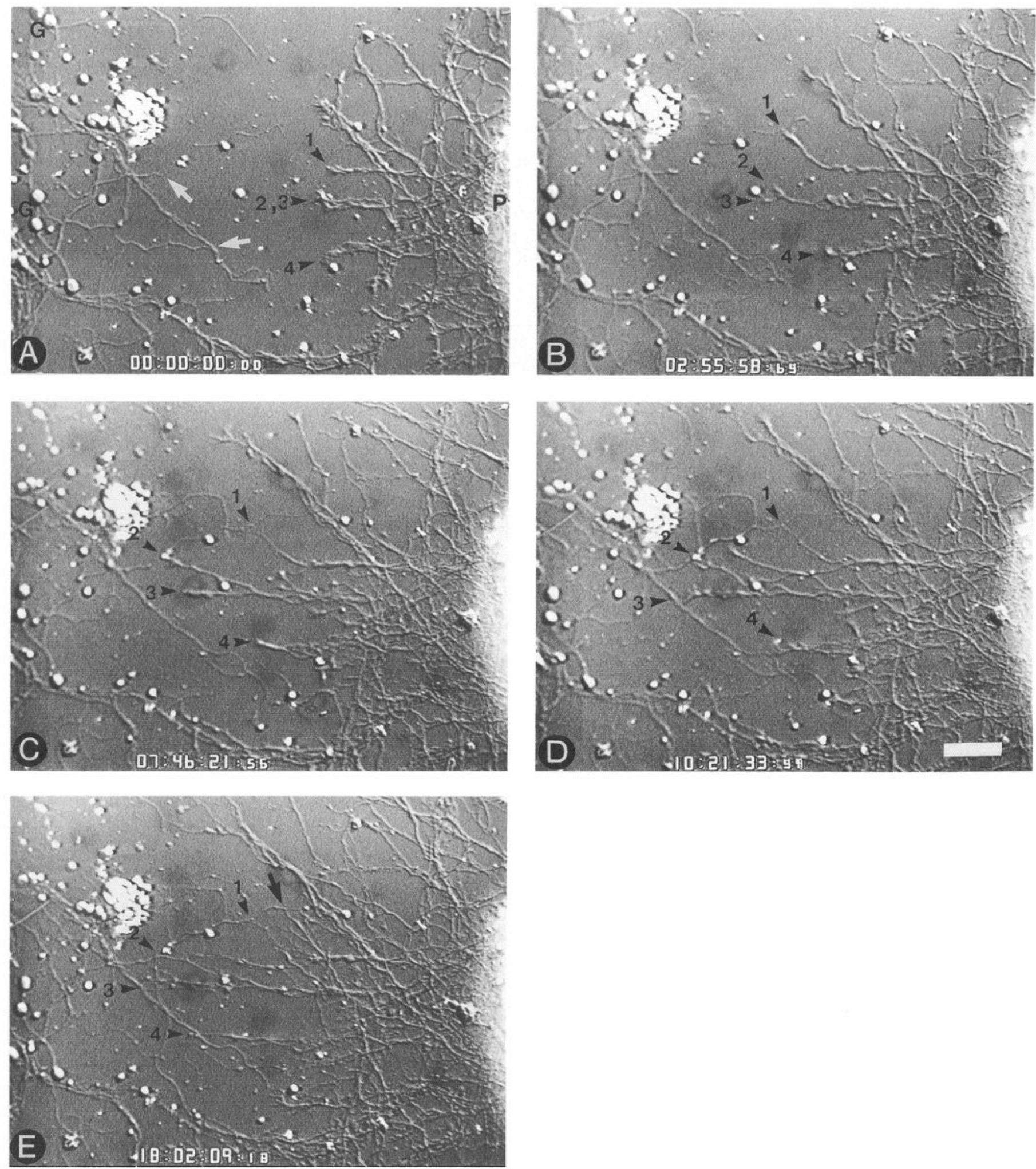

Figure 11. Long-term observation of pontine growth cones stopping at granule neurons. VEDIC time-lapse micrographs of formation and maintenance of contacts between pontine growth cones and granule neurons. Times at the bottom of the panels are hours:minutes: seconds: hundredths of a second. $A$, Pontine explant $(P)$ extends several neurites tipped by active growth cones (numbered arrowheads) toward granule cell neurites (e.g., white arrow) and somata (e.g., $G$ ). B, A growth cone contacts a granule cell neurite (arrowhead 1 ). This contact is maintained throughout $16 \mathrm{hr}$ of observation. Additional contacts are formed in $C$ (growth cone 2 ) and $D$ (growth cone 3 ). Growth cone 4 made contact with a granule cell neurite sometime between $D$ and $E$. Once established, all four contacts were maintained throughout the remainder of the observation period. During the $7 \mathrm{hr}, 40 \mathrm{~min}$ between $D$ and $E$, growth of some pontine neurites resulted in new pontine-granule cell contacts (e.g., arrow), but earlier contacts are maintained without renewed growth. Scale bar, $50 \mu \mathrm{m}$. 
neurons (Baird, 1991). In the presence of TTX or a glutamate antagonist pontine neurite extension is no longer inhibited and neurites extend long distances over granule neuron monolayers.

In summary, the present study provides evidience that cellcell interactions in target regions of developing brain provide regulatory signals for axon extension. Whcrcas axoaxonal and axoglial interactions in the developing cerebellum promote the growth of pontine axons in vitro, interactions with target granule neurons interrupt axon extension. In the cerebellar cortex, the interruption of mossy fiber extension by granule neurons is likely to play several roles in the patterning of synaptic innervation by mossy fibers. First, cell-cell interactions with granule neurons may allow axons to terminate only al appropriate target cells. Second, the stop signal provided by target neurons may help keep the level of innervation in check, by preventing axons from contacting too many target cells. Third, the relative levels of a stop signal and growth support signals may specify the form of synaptic contacts, for example, whether axons stop at an individual cell, then move on to make additional contacts, or whether a single axon arborizes profusely onto a single neuron, as in the sensory-L1 motoneuron relationship in Aplysia (Glansman ct al., 1989) or climbing fiber-Purkinje cell relationship (Ramon y Cajal, 1911; Palay and Chan-Palay, 1974; Mason et al., 1990). Finally, a stop signal on the axons of granule neurons, the parallel fibers, may reduce mossy fibers extension beyond the internal granule cell layer, into the molecular layer. The role of astroglial cells in the establishment of axonal projections appears to subserve the dominant role of axoneuronal interactions; glia support axon growth until the growing tip contacts an appropriate target cell.

\section{References}

Abercrombie, Heaysman JE (1953) Observations on the social behaviour of cells in tissue culture. I. Speed of movement of chick heart fibroblasts in relation to their mutual contacts. Exp Cell Res 5:111131.

Allen RD, Allen NS, Travis JC (1981) Video-enhanced contrast, differential interference contrast (AVEC-DIC) microscopy: a new method capable of analyzing microtubule-related motility in the reticulopodial network of Allogromia laticollaris. Cell Motil 1:291-302.

Altman J (1982) Morphological development of the rat cerebellum and some of its mechanisms. In: The cerebellum-new vistas (Palay SL, Chan-Palay V, eds), pp 8-49. New York: Springer.

Altman J, Bayer SA (1978) Prenatal development of the cerebellar system in rat. II. Cytogenesis and histogenesis of the inferior olive, pontine gray, and the precerebellar reticular nuclei. J Comp Neurol 178:49-76.

Armson PF, Bennett MR, Raju TR (1987) Retinal ganglion cell survival and neurite regeneration requirements: the change from Müller cell dependence to superior colliculi dependence during development. Dev Brain Res 32:207-216.

Baird DH (1991) Regulation of afferent growth by target neurons in vitro is affected by TTX, high magnesium or a glutamate antagonist. Soc Neurosci Abstr 17:532.

Baird DH, Baptista CA, Hatten ME, Mason CA (1990) Cerebellar mossy fiber, but not climbing fiber, elongation is interrupted by target granule neurons in vitro. Soc Neurosci Abstr 16:1127.

Bandtlow C, Zachleder T, Schwab ME (1990) Oligodendrocytes arrest neurite growth by contact inhibition. J Neurosci 10:3837-3848.

Baorto DM, Shelansk ML (1990) Effect of astrocytic age and confluence on the growth of PC 12 neurites. Soc Neurosci Abstr 16:169.

Bartlett WP, Banker GA (1984) An electron microscopic study of the development of axons and dendrites by hippocampal neurons in culture. I. Cells which develop without intercellular contacts. J Neurosci 4:1944-1953.

Bovolenta P, Mason CA (1987) Growth conc morphology varies with position in the developing mouse visual pathway from retina to first targets. J Neurosci 7:1447-1460.
Bovolenta P, Liem RKH, Mason CA (1984) Development of cerebellar glia: transitions in form and cytoskeletal content. Dev Biol 102: 248-259.

Brodal P, Walberg F (1977) The pontine projection to the cerebellar anterior lobe. An experimental study in the cat with retrograde transport of horseradish peroxidase. Exp Brain Res 29:233-248.

Burns FR, von Kannen S, Guy L, Raper JA, Kamholz J, Chang S (1991) DM-GRASP, a novel immunoglobulin superfamily axonal surface protein that supports neurite extension. Neuron 7:209-220.

Catalano SM, Robertson RT, Killackey HP (1991) Early ingrowth of thalamocortical afferents to the neocortex of the prenatal rat. Proc Natl Acad Sci USA 88:2999-3003.

Cox C, Muller B, Bonhoeffer F (1990) Axonal guidance in the chick visual system: posterior tectal membranes induce collapse of growth cones from temporal retina. Neuron 2:31-37.

Davies JA, Cook GMW, Stern CD, Keynes RJ (1990) Isolation from chick somites of a glycoprotein fraction that causes collapse of dorsal root ganglion growth cones. Neuron 4:11-20.

Denis-Donini A, Glowinski J, Prochiantz A (1983) Specific influence of striatal target neurons on the in vitro outgrowth of mesencephalic dopaminergic neurites: a morphological quantitative study. J Neurosci 11:2292-2299.

Dodd J, Jessell TM (1988) Axon guidance and the patterning of neuronal projections in vertebrates. Science 242:692-699.

Edmondson JC, Hatten ME (1987) Glial-guided granule neuron migration in vitro: a high-resolution time-lapse video microscopic study. J Neurosci 7:1928-1934.

Elkins T, Zinn K, McAllister L, Hoffmann MF, Goodman CS (1990) Genetic analysis of a Drosophila neural cell adhesion molecule: interaction of fasciclin I and abelson tyrosine kinase mutations. Cell 60:565-575.

Fallon J (1985) Preferential outgrowth of CNS neurites on astrocytes and Schwann cells as compared with non-glial cells in vitro. J Cell Biol 100:198-207.

Glanzman DL, Kandel ER, Schacher S (1989) Identified motor neuron regulates neurite outgrowth and synapse formation of Aplysia sensory neurons in vitro. Neuron 3:441-450.

Godement P, Mason CA (1990) Behavior of live retinal axon growth cones in the optic chiasm. Soc Neurosci Abstr 16:1125.

Godement P, Vanselow J, Thanos S, Bonhoeffer F (1987) A study in developing visual systems with a new method of staining neurones and their processes in fixed tissue. Development 101:697-713.

Godement P, Salaün J, Mason CA (1990) Retinal axon pathfinding in the optic chiasm: divergence of crossed and uncrossed fibers. Neuron 5:173-186.

Gravel C, Hawkes R (1990) Parasagittal organization of the rat cerebellar cortex: direct comparison of Purkinje cell compartments and the organization of the spinocerebellar projection. J Comp Neurol 291:79-102.

Harrelson AL, Goodman CS (1988) Growth cone guidance in insects: fasiclin II is a member of the immunoglobulin superfamily. Science 242:700-708.

Harris WA, Holt CA, Bonhoeffer F (1987) Retinal axons with and without their somata, growing to and arborizing in the tectum of frog embryos: a time-lapse video study of single fibers in vivo. Development 101:123-133.

Hatten ME (1985) Neuronal regulation of astroglial morphology and proliferation in vitro. J Cell Biol 100:384-396.

Hatten ME (1987) Neuronal inhibition of astroglial cell proliferation is membrane mediated. J Cell Biol 104:1353-1360.

Hatten ME, Francois AM (1981) Cell assembly patterns of embryonic and early postnatal mouse cerebellar cells on lectin-derivatized culture substrata. Dev Biol 87:102-113.

Hatten ME, Liem RKH, Mason CA (1984) Two forms of cerebellar glial cells interact differently with neurons in vitro. J Cell Biol 98:193204.

Hatten ME, Fishell G, Stitt T, Mason CA (1991) Glia as a scaffold for development of the CNS. Semin Neurosci 2:455-465.

Huber G, Matus A (1984) Differences in the cellular distribution of two microtubule-associated proteins, MAP1 and MAP2, in rat brain. J Neurosci 4:151-160.

Inouye S (1986) Video microscopy. New York: Plenum.

Ivins JK, Pittman RK (1989) Growth cone-growth cone interactions in cultures of rat sympathetic neurons. Dev Biol 135:147-157.

Jay DG, Keshishian H (1990) Laser inactivation of Pasciclin I disrupts axon adhesion of grasshopper pioneer neurons. Nature 348:548-550. 
Jessell TM (1988) Adhesion molecules and the hierarchy of neural development. Neuron 1:1-13.

Kapfhammer J, Raper J (1987) Collapse of growth cone structure on contact with specific neurites in culture. J Neurosci 7:201-212.

Keynes R, Cook G (1990) Cell-cell repulsion: clues from the growth cone? Cell 62:609-610.

Landis DMD, Weinstein LA, Halperin JJ (1983) Development of synaptic junctions in cerebellar glomeruli. Dev Brain Res 8:231-245.

Landmesser L, Dahm L, Tang J, Rutishauser U (1990) Polysialic acid as a regulator of intramuscular nerve branching during embryonic development. Neuron 4:655-667.

Liem RKH (1982) Simultaneous separation and purification of neurofilament and glial filament protcins from the brain. J Neurochem 38:142-150.

Liem RKH, Chin SSM, Moraru E, Wang E (1985) Monoclonal antibodies to epitopes on different regions of the 200,000 Dalton neurofilament protein. Exp Cell Res 156:419-428.

Lipton SA, Kater SB (1989) Neurotransmitter regulation of neuronal outgrowth, plasticity and survival. Trends Neurosci 12:265-270.

Lund RD, Chang F-LF, Hankin M, Lagenaur CF (1985) Use of a species specific antibody for demonstrating mouse neurons transplanted to rat brains. Neurosci Lett 61:221-226.

Marin-Padilla M (1985) Neurogenesis of the climbing fibers in the human cerebellum: a Golgi study. J Comp Neurol 235:82-96.

Mason CA (1987) The development of cerebellar mossy fibers and climbing fibers: embryonic and postnatal features. In: Neurology and neurobiology (Chan-Palay V, Palay S, series eds), Vol 22, New concepts in cerebellar neurobiology (King JS, ed), pp 57-88. New York: Liss.

Mason CA, Gregory E (1984) Postnatal maturation of cerebellar mossy and climbing fibers: transient expression of dual features on single axons. J Neurosci 4:1715-1735.

Mason CA, Godement P (1991) Growth cone form reflects interactions in visual pathways and cerebellar targets. In: The nerve growth cone (Letourneau PC, Kater SB, Macagno ER, eds), pp 405-423. New York: Raven.

Mason CA, Edmondson JC, Hatten ME (1988) The extending astroglial process: development of glial cell shape, the growing tip, and interactions with neurons. J Neurosci 8:3124-3134.

Mason CA, Christakos S, Catalano SM (1990) Early climbing fiber interactions with Purkinje cells in postnatal mouse cerebellum. J Comp Neurol 297:77-90.

Moorman SJ, Hume RI (1990) Growth cones of chick sympathetic preganglionic neurons in vitro interact with other neurons in a cellspecific manner. J Neurosci 10:3158-3163.

Neugebauer KM, Tomaselli KJ, Lilien J, Reichardt LF (1988) N-cadherin, NCAM, and integrins promote retinal neurite outgrowth on astrocytes in vitro. J Cell Biol 107:1177-1188.

Noble M, Fok-Seang J, Cohen J (1984) Glia are a unique substrate for the in vitro growth of central nervous system neurons. J Neurosci 4:1892-1903.

Norris CR, Kalil K (1990) Morphology and cellular interactions of growth cones in the developing corpus callosum. J Comp Neurol 293: $268-281$.

O'Connor TP, Duerr JS, Bentley D (1990) Pioneer growth cone steering decisions mediated by single filopodial contacts in situ. J Neurosci 10:3935-3946.

O'Donoghue DL, Martin GF, King JS (1987) The timing of granule cell differentiation and mossy fiber morphogenesis in the opossum. Anat Embryol 175:341-354.
O'Rourke NA, Fraser SE (1990) Dynamic changes in optic fiber terminal arbors lead to retinotopic map formation: an in vivo confocal microscopic study. Neuron 5:159-171.

Palay S, Chan-Palay V (1974) Cerebellar cortex, cytology and organization. New York: Springer.

Patterson PH (1988) On the importance of being inhibited, or saying no to growth cones. Neuron 1:263-267.

Rakic P (1971) Neuron-glia relationships during granule cell migration in developing cerebellar cortex: a Golgi and electron microscopic study in Macacus rhesus. J Comp Neurol 141:283-312.

Ramon y Cajal S (1911) Histologie du systeme nerveux de l'homme et des vertebrés, Vols I and II. Paris: Maloine.

Raper JA, Kapfhammer JP (1990) The enrichment of a neuronal growth cone collapsing activity from embryonic chick brain. Neuron 4:21-29.

Reichardt LF, Bossy B, Carbonetto S, DeCurtis I, Emmett C, Hall DE, Ignatius MJ (1990) Neuronal receptors that regulate axon growth. Cold Spring Harbor Symp Quant Biol 55:341-350.

Rutishauser U (1989) Membrane apposition as a regulating parameter in cell-cell interactions. In: The assembly of the nervous system (Landmesser LT, ed), pp 137-150. New York: Liss.

Rutishauser U, Jessell TM (1988) Cell adhesion molecules in vertebrate neural development. Physiol Rev 68:819-857.

Shatz CJ (1991) Impulse activity and the patterning of connections during CNS development. Neuron 5:745-756.

Smith GM, Miller RH, Silver J (1986) Changing role of forebrain astrocytes during development, regencrative failure, and induced regeneration upon transplantation. J Comp Neurol 251:23-43.

Sotelo C (1982) Synaptic remodeling in agranular cerebellum. In: The cerebellum - new vistas (Palay SL, Chan-Palay V, eds), pp 50-68. New York: Springer.

Sretavan DW (1990) Axon navigation at the mammalian optic chiasm: direct observation using fluorescent time-lapse video microscopy. Soc Neurosci Abstr 16:1125.

Stuermer CAO (1990) Target recognition and dynamics of axonal growth in the retinotectal system of fish. Neurosci Res [Suppl] 13: S1-S10.

Thanos S, Bonhoeffer F, Rutishauser U (1984) Fiber-fiber interaction and tectal cues influence the development of the chicken retinotectal projection. Proc Natl Acad Sci USA 81:1906-1910.

Tomaselli KJ, Neugebauer KM, Bixby JL, Lilien J, Reichardt LF (1988) $\mathrm{N}$-cadherin and integrins: two receptor systems that mediate neuronal process outgrowth on astrocyte surfaces. Neuron 1:33-43.

Tosney KW, Oakley RA (1990) Perinotochordal mesenchyme acts as a barrier to axon advance in the chick embryo: implications for a general mechanism of axon guidance. Exp Neurol 109:75-89.

Wang L-C, Baird DH, Hatten ME, Mason CA (1990) Astroglial differentiation, not "age," is critical for neurite outgrowth. Soc Neurosci Abstr 16:1005

Walter J, Kern-Veits B, Huf J, Stolze B, Bonhoeffer F (1987) Recognition of position-specific properties of tectal cell membranes by retinal axons in vitro. Development 101:685-696.

Yaginuma H, Shunsaku H, Kunzi R, Oppenheim RW (1991) Pathfinding by growth cones of commissural interneurons in the chick embryo spinal cord: a light and electron microscopic study. J Comp Neurol 304:78-102.

Yayon A, Klagsbrun M, Esko JD, Leder P, Ornitz DM (1991) Cell surface, heparin-like molecules are required for binding of basic fibroblast growth factor to its high affinity receptor. Cell 64:841-848. 